\title{
Eutrophication and sediment-water exchange of total petroleum hydrocarbons and heavy metals of Hashilan wetland, a national heritage in NW Iran
}

\author{
Sajjad Abbasi ${ }^{1,2}$ (D) Sara Sheikh Fakhradini ${ }^{1} \cdot$ Neamatollah Jaafarzadeh $^{3} \cdot$ Pooria Ebrahimi $^{4} \cdot{\text { Shirin } \text { Yavar } \text { Ashayeri }}^{1}$
}

Received: 1 September 2021 / Accepted: 30 November 2021 / Published online: 19 December 2021

(c) The Author(s) 2021

\begin{abstract}
The heavy metal(loid)s concentrations in water and sediments were analyzed in the Hashilan wetland to assess the spatial distribution, pollution status, fate, partitioning, and ecological risk and also to identify the heavy metal(loid)s sources in sediments using PMF (Positive Matrix Factorization) and APCs-MLR (absolute principal component score-multiple linear regression) receptor models. According to the pollution indices, $(\mathrm{Ni}, \mathrm{Cu}, \mathrm{Cr}, \mathrm{Mo})$, and $(\mathrm{Zn}, \mathrm{Cr}$, and $\mathrm{Cu})$ are considered the most important pollutants in sediments and water, respectively. $\mathrm{Ni}, \mathrm{Cr}$, and $\mathrm{Cu}$ are the main contributors to ecological risks in sediments of some stations. The potential ecological risk assessment proposed low ecological risk in water of the study area. Higher distribution coefficient $\left(K_{p}\right)$ values of $\mathrm{Ni}, \mathrm{Cr}, \mathrm{Mn}, \mathrm{Cu}, \mathrm{Co}, \mathrm{Pb}, \mathrm{As}$, and $\mathrm{Zn}$ indicated the majority of these heavy metals present in the sediments; whereas, the majority of Cd concentration occurs in water. PMF and APCs-MLR results indicated the natural sources were the main factors affecting the concentrations of $\mathrm{Ni}, \mathrm{Cr}, \mathrm{Zn}, \mathrm{Al}, \mathrm{Co}, \mathrm{Fe}, \mathrm{Pb}, \mathrm{As}, \mathrm{Cd}$ and somewhat $\mathrm{Cu}$. Mixed natural and agricultural activities are the main sources of $\mathrm{Mo}$, and somewhat $\mathrm{Cu}$. According to the results, there is low pollution of TPH (total petroleum hydrocarbons) in the sediment samples. Also, phosphate $\left(\mathrm{PO}_{4}{ }^{2-}\right)$ and nitrate $\left(\mathrm{NO}_{3}{ }^{-}\right)$ concentrations were below the recommended permissible limits at all sampling sites except the $\mathrm{S} 8$ station for $\mathrm{NO}_{3}^{-}$.
\end{abstract}

Keywords Heavy metal $\cdot$ TPH $\cdot$ Eutrophication $\cdot$ Wetland $\cdot$ Hashilan $\cdot$ Iran

\section{Introduction}

Wetlands are recognized to be productive ecosystems due to water quality protection, sinks for nutrients and pollutants, water cycling maintenance, controlling floods and flows, groundwater recharge, and so on (Andreu et al. 2016;

Responsible Editor: Alexandros Stefanakis

Sajjad Abbasi

sajjad.abbasi.h@gmail.com; sajjad.abbasi@shirazu.ac.ir

1 Department of Earth Sciences, College of Science, Shiraz University, 71454 Shiraz, Iran

2 Department of Radiochemistry and Environmental Chemistry, Faculty of Chemistry, Maria Curie-Skłodowska University, 20-031 Lublin, Poland

3 Environmental Technologies Research Center, Ahvaz Jundishapur University of Medical Sciences, Ahvaz, Iran

4 Department of Earth, Environmental and Resources Sciences, University of Naples Federico II, 80126 Naples, Italy
Tuboi et al. 2018). Nowadays, anthropogenic stressors such as population growth, resources overexploitation, economic development, and agricultural encroachments and drainage have affected and polluted the wetland environment (Tuboi et al. 2018). Metal Pollutants enter the aquatic habitats not only from natural sources including weathering, erosion, and soil leaching but also from anthropogenic activities such as urbanization, industrial and agricultural activities (Abbasi et al. 2019; Strady et al. 2017) and endanger humans and animals health as a result of their toxicity, persistence, and bioaccumulation via the food chain.

Total petroleum hydrocarbon (TPH) is a homogeneous mixture including hundred chemical compounds that originally come from crude oil. These compounds generally enter the aquatic environment through several anthropogenic activities such as contaminated lands, pesticides, vehicle emissions, oil spillage, automobile oils, or different harmful organic substances (Chen et al. 2020; Li et al. 2019). Several products of TPH contain heavy metals which are present in crude oil or may also be added as chemicals to these products (Defarge et al. 
2018). However, numerous pesticides contain As, $\mathrm{Co}, \mathrm{Cr}$, $\mathrm{Ni}$, and $\mathrm{Pb}$ elements and $\mathrm{Cd}, \mathrm{Co}, \mathrm{Cu}, \mathrm{Ni}, \mathrm{Pb}$, and $\mathrm{Zn}$ metals as impurities are found in different fertilizers. Moreover, $\mathrm{Fe}, \mathrm{Mn}, \mathrm{Zn}, \mathrm{Pb}$, and $\mathrm{Ni}$ are present in some herbicides (Gimeno-García et al. 1996). Eating, breathing, and direct contact with contaminated soil, water, and sediments are considered the path of their entry into the human body (Quiñonez-Plaza et al. 2017). Also, these compounds can create negative effects on human and biota health, depending on the different compounds values present in the TPH (Quiñonez-Plaza et al. 2017; Zhou et al. 2014).

Sediments as a part of aquatic environments have a significant role in biochemical cycling and food web protection (Islam et al. 2018). Sediments provide a large capacity to accumulate a large fraction of heavy metal(loid)s as a result of hydrolysis, co-precipitation, and adsorption processes while a small portion of heavy metals remains in the water column (Hou et al. 2013; Wu et al. 2017). Also, sediments could act as a secondary source due to environmental conditions change and releasing metals into the water, affecting a health risk to aquatic biota due to their high bioavailability (Cui et al. 2019). However, metal(loid) partitioning between water and sediment is specified due to oxidation/reduction and precipitation/dissolution reactions of heavy metal(loid) $\mathrm{s}$ in sediments (Duarte et al. 2014).

Water resources are essential in sustainable societal development and natural processes including erosion and climatic conditions, and anthropogenic activities, such as industrial and agricultural practices affect water resources and a large amount of pollutants is discharged into the water reservoirs (Lyu et al. 2021). Eutrophication is considered as an important environmental problem in the world. This phenomenon occurs under the influence of natural factors and human activities, which increase the amount of algae and aquatic plants and decrease the dissolved oxygen of the water (Lin et al. 2020, 2021). Thus, the evaluation of water quality is a significant prerequisite for the conservation, control of water bodies, and safety guaranty of the regional water environment.

This study focuses on Hashilan wetland, which is one of the most important agricultural areas in Kermanshah province as a result of fertile soils, sufficient water resources and suitable climate. Also, Hashilan wetland is one of the unique flora and fauna regions of this Province. Unfortunately, discharge of agricultural runoff, containing different types of contaminants such as microplastic particles (Abbasi 2021), heavy metals, fertilizers, and herbicides into the wetland has affected human and biota health. Also, the presence of tourists in this area can also be a threat to this wetland. Thus, decision-makers need to evaluate heavy metal(loid)s values in water and sediment environments to specify the sources, fate, and ecological risk of pollutants and then eliminate water and sediment pollution via urgent actions.
Worth mentioning that the novelty of the current study is to investigate organic and inorganic contaminants comprehensively in the water and sediment of Hashilan Wetland for the first time. The major purposes of this research are 1) to specify the concentration, distribution, pollution rate and ecological risk of heavy metal(loid)s in water, and sediment the Hashilan wetland, 2) to determine the metal(loid) s source apportionment in the sediment, 3 ) to identify affective factors on metal(loid)s partitioning between surface water and sediment, 4) to evaluate the trophic state of the water samples, and 5) to investigate the pollution rate of $\mathrm{TPH}$.

\section{Material and methods}

\section{Study area}

Hashilan wetland, as a significant freshwater wetland in the Kermanshah Province, has been located at the Hashilan village, being $26 \mathrm{~km}$ northwest of Kermanshah city. It lies between $46^{\circ}, 51^{\prime}$ to $46^{\circ}, 54^{\prime}$ eastern longitude and $34^{\circ}, 34^{\prime}$ to $35^{\circ}, 34^{\prime}$ northern latitude (Fig. 1). This Wetland constitutes a unique feature in the Middle East which is called "karstic spring wetland," an ecosystem mostly found in the Zagros Mountains of Iran. Geologically, its catchment basin and the aquifers of its water sources are located in the limestone formations of the Triassic-Jurassic age. Hashilan Wetland is located in a syncline bordered by two anticlines in the northeast (Khorin anticline) and southwest (Biston anticline). Surveying the wetland on a large scale is a part of the Miandarband plain which surrounds the two anticlines, contains several other wetlands and has two rivers namely Razavar in the north and Gareso in the south (Abbasi et al. 2021).

The mean annual precipitation is about $450 \mathrm{~mm}$, respectively. Also, the average temperature is $22{ }^{\circ} \mathrm{C}$. The areal coverage of wetland is about $450 \mathrm{ha}$. Sabz Ali spring, originating from the Khorein Mountains located on the northern border of the wetland supply the wetland water. This wetland consists of 110 islands ranging from 0.1 to 1 ha in size, which causes the water to be distributed among the islands as the small and big channels. This wetland has been suffered from high-intensity agricultural activities, which is the main occupation of the local inhabitants. It should be noted the wetland supports a significant and unique population of flora and fauna.

\section{Water and sediment sampling and analysis}

Sixteen surface sediment samples and 6 water samples were collected in September 2019 covering an area of about $450 \mathrm{ha}$. In each sampling location, about $2 \mathrm{~kg}$ surface 
Fig. 1 Map of the study area and sampling sites in Hashilan's wetland area

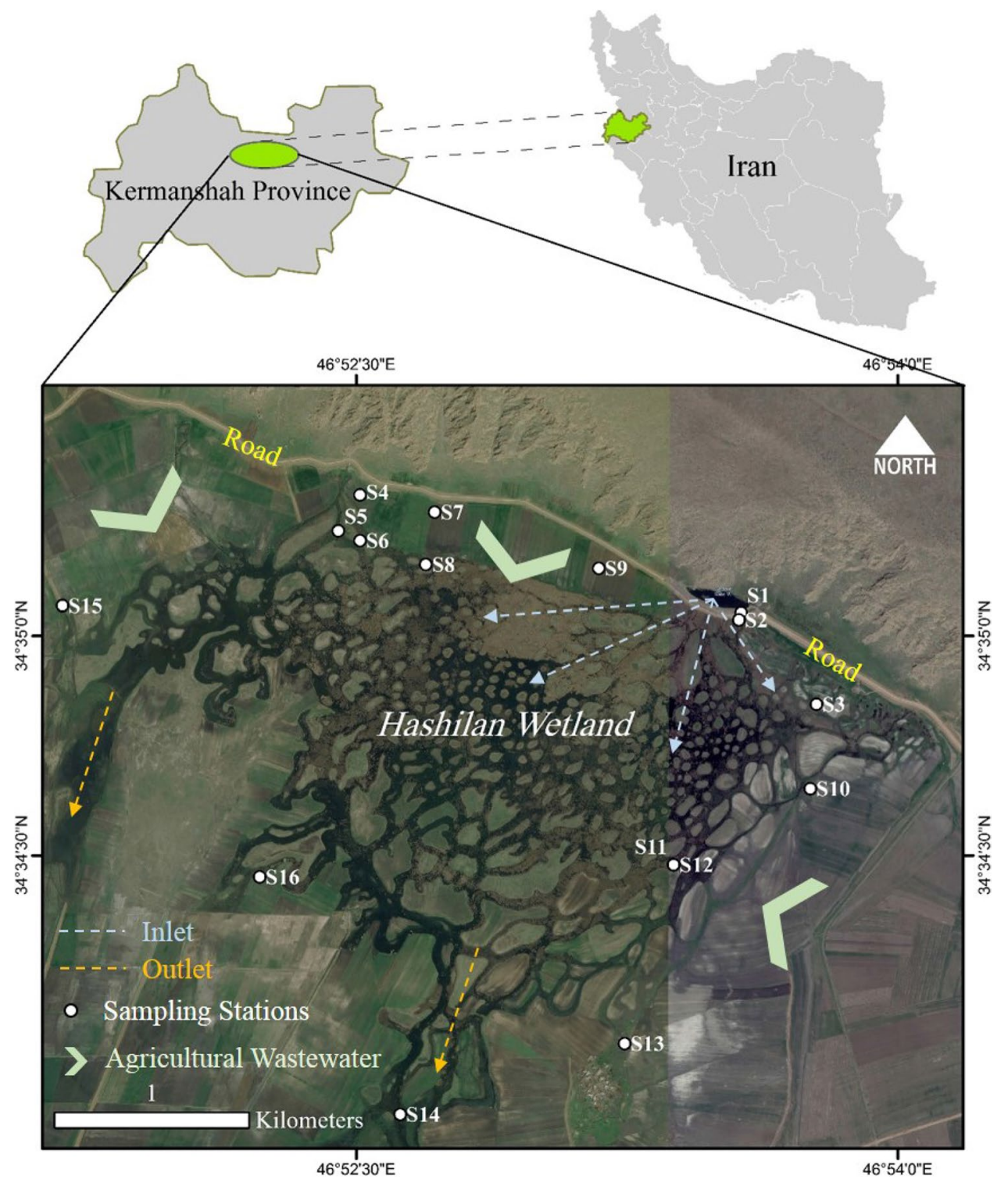

sediment $(0-5 \mathrm{~cm})$ was collected via a Van Veen stainless steel grab and placed in a clear polyethylene bag. Then, the samples were transferred to the laboratory in an iced box. It should be mentioned that the water samples were only taken from monitoring stations where the sediments were surrounded by water. The sampling stations information covering the whole study area is illustrated in Table S1 (supporting information).

In the laboratory, the sediment samples were air-dried at room temperature. Agate Mortar and pestle were used to crush the sediment. Larger debris such as plant leaves and pieces of glass were separated (2-mm sieve) after being air-dried at room temperature. Finally, the samples were passed through a 220 mesh $(63 \mu \mathrm{m})$ for elemental analysis and then homogenized. Thus, the samples were measured using inductively coupled plasma mass spectrometry (ICPMS) at Zarazma Mineral Studies Company, Iran.
Usually, sites close to roads indicate higher TPH contents than other areas. Therefore, to evaluate the TPH concentrations of Hashilan sediments, a total of 5 surface sediment samples were collected from stations close to the roads and agricultural lands where agricultural machinery passes and immediately put in dark glass bottles which were already washed with n-hexane and sealed by aluminum foil caps. The collected samples were transported to the laboratory of the Isfahan University of Technology in an ice-box at $4{ }^{\circ} \mathrm{C}$ and stored at $-20{ }^{\circ} \mathrm{C}$ until analysis.

The surrogate standards (Pyrene-D10 lot:10,510 semivolatile internal standards) and ultra-sonic bath (KUDOS Modell SK3210LHC) were used during the extraction of approximately $5 \mathrm{~g}$ per dried sample. For the TPH calibration, the pyr-D10 was used as the internal standard. The samples were then collected by means of a 30-ml organic solvent mix (DCM) of 1:1 v/v at room temperature (N-hexane and DCM) 
for around $30 \mathrm{~min}$. The solution is applied with amorphous sulfate sodium and the next step is $2 \mathrm{~mL}$ of dried extracts. The extract close to sediment samples was washed with a silica gel column (Abbasi and Keshavarzi 2019; Sheikh Fakhradini et al. 2019). Following the EPA 418 protocol, the samples for TPH were analyzed. The samples have then been analyzed using a High Leistung Fluorescence Detector (HP-1046) Hewlett-Packard (HP) 1090 in the laboratory of Isfahan University of Technology using a RIGOL L-3000 High-Performance Liquid Chromatographer (HPLC, RIGOL Technologies, Inc., Beijing, China) equipped with a RIGOL L-3500 UV-vis detector (RIGOL Technologies, Inc., Beijing, China) and a Hewlett-Packard 1046 A fluorescence detector (Agilent Technologies, California, USA). A rotative vacuum evaporator concentrated the extracts to $1 \mathrm{ml}$. The PAHs analysis was based on $20 \mu \mathrm{l}$ of each extract. At a rate of flux of $1 \mathrm{ml} / \mathrm{min}$ and temperature was set at $35^{\circ} \mathrm{C}$ the mobile step was acetonitrile/water in gradient mode.

The water samples were immediately purified in the field by $0.45-\mu \mathrm{m}$ Teflon filters. For PTEs analysis, the samples were acidified to $\mathrm{pH}<2$ with ultrapure nitric acid $\left(\mathrm{HNO}_{3}\right)$ and kipped in dark polyethylene bottles at $4{ }^{\circ} \mathrm{C}$ prior to analysis of PTEs concentration by inductively coupled plasmamass spectrometry (ICP-MS) at Zarazma Mineral Studies Company, Iran. Temperature, $\mathrm{pH}$, and salinity of water samples were evaluated on-site using portable measuring devices (Eutech Instruments, PCD650).

\section{Quality assurance and quality control}

Quality assurance and control (QA/QC) included the procedural blank, analytical duplicates and use of certified reference material (OREAS reference materials) for water and sediment samples. The recovery percentages of the investigated PTEs ranged from 80 to $110 \%$, and the blank was below the detection limit. Concentrations of heavy metal(loid)s were recorded as $\mathrm{mg} / \mathrm{kg}$ dry weight for sediments, and $\mu \mathrm{g} / \mathrm{L}$ for water in this study.

Generally, the average recovery for TPH in sediment was approximately $88-95 \%$. Reagent blanks, analytical duplicates/replicates, and analysis of the standard reference material (Dr. Ehrenstorfer GmbH Alkanes-Mix 10, and SigmaAldrich Co. LLC EPA 525 PAH Mix A and EPA 525 PAH Mix B) were processed.

\section{Data analysis}

In order to estimate the pollution rate of sediments and water, this paper utilized different types of indices including enrichment factor $(E F)$, geoaccumulation index $\left(I_{\text {geo }}\right)$, contamination factor $(C f)$, Nemerow pollution index $(N P I)$, modified pollution index (MPI), and heavy metal toxic load (HMTL) to specify the pollution degree of PTEs in Hashilan wetland. In this study, potential ecological risk index $(R I)$, modified ecological risk index $(M R I)$, sediment quality guidelines $(S Q G s)$, toxic units $(T U s)$, and toxic risk index (TRI) were applied to estimate the ecological risk in water and sediments of the wetland. To recognize the potential source of PTEs in sediments, Spearman correlation analysis, principal component analysis (PCA)/ absolute principal component scores (APCS) and positive matrix factorization (PMF) model were utilized. Also, partition coefficient $\left(K_{p}\right)$ was calculated to determine the interaction of PTEs between water and sediment phases. The details of the mentioned indices are described in the supporting information.

\section{Results and discussion}

\section{Concentration of total petroleum hydrocarbons (TPH) in sediments}

Total petroleum hydrocarbons (TPHs) values as the sum of aliphatic and aromatic hydrocarbons ranged from 4.2 to $76 \mathrm{mg} / \mathrm{kg}$ averaging $30.44 \pm 28 \mathrm{mg} / \mathrm{kg}$ in sediment samples. The highest value of TPH was measured at the S2 site while $\mathrm{S} 1$ represented the lowest TPH concentration. The TPH values higher than $500 \mathrm{mg} / \mathrm{kg}$ in sediments indicate severely polluted sediments, while their contents below $10 \mathrm{mg} / \mathrm{kg}$ show no pollution (Akhbarizadeh et al. 2016; Kucuksezgin et al. 2012). Therefore, TPH concentrations in Hashilan sediment samples can be categorized as no polluted in site $\mathrm{S} 1$, and low polluted for the other collected sediment samples. Totally, the impact of human activities on the TPH concentrations in the Hashilan sediments was low.

TPH values in the sediments of Hashilan wetland are lower than those reported from Khark Island (80 to $618 \mathrm{mg}$ / $\mathrm{kg}$; Iran) (Akhbarizadeh et al. 2016), Yangtze estuary (50.05-428.50 mg/kg; China) (Li et al. 2019); Bohai Bay (6.3-535 mg/kg; China) (Zhou et al. 2014), Barnegat-BayLittle Egg Harbor Estuary, USA (47-1003 mg/kg; USA) (Vane et al. 2008), but higher than those from the Bay of Bengal (1.8-40 mg/kg; India) (Venkatachalapathy et al. 2010) Bizerte lagoon (0.05-20 mg/kg; Tunisia) (Mzoughi et al. 2005); mangroves of the northern Persian Gulf (ND$1.7 \mathrm{mg} / \mathrm{kg}$; Iran) (Mohebbi-Nozar et al. 2015) and Izmir Bay (0.43-7.8 mg/kg; Turkey) (Kucuksezgin et al. 2006).

\section{Concentration of heavy metal(loid)s in water and sediments}

The PTEs values and statistical parameters in the collected sediments and surface water of the Hashilan wetland are summarized in Table 1. Regarding Levene's test for equality of variances tests, all metal(loid)s concentrations in soil and sediment zones had values of greater than 0.05 , proposing 


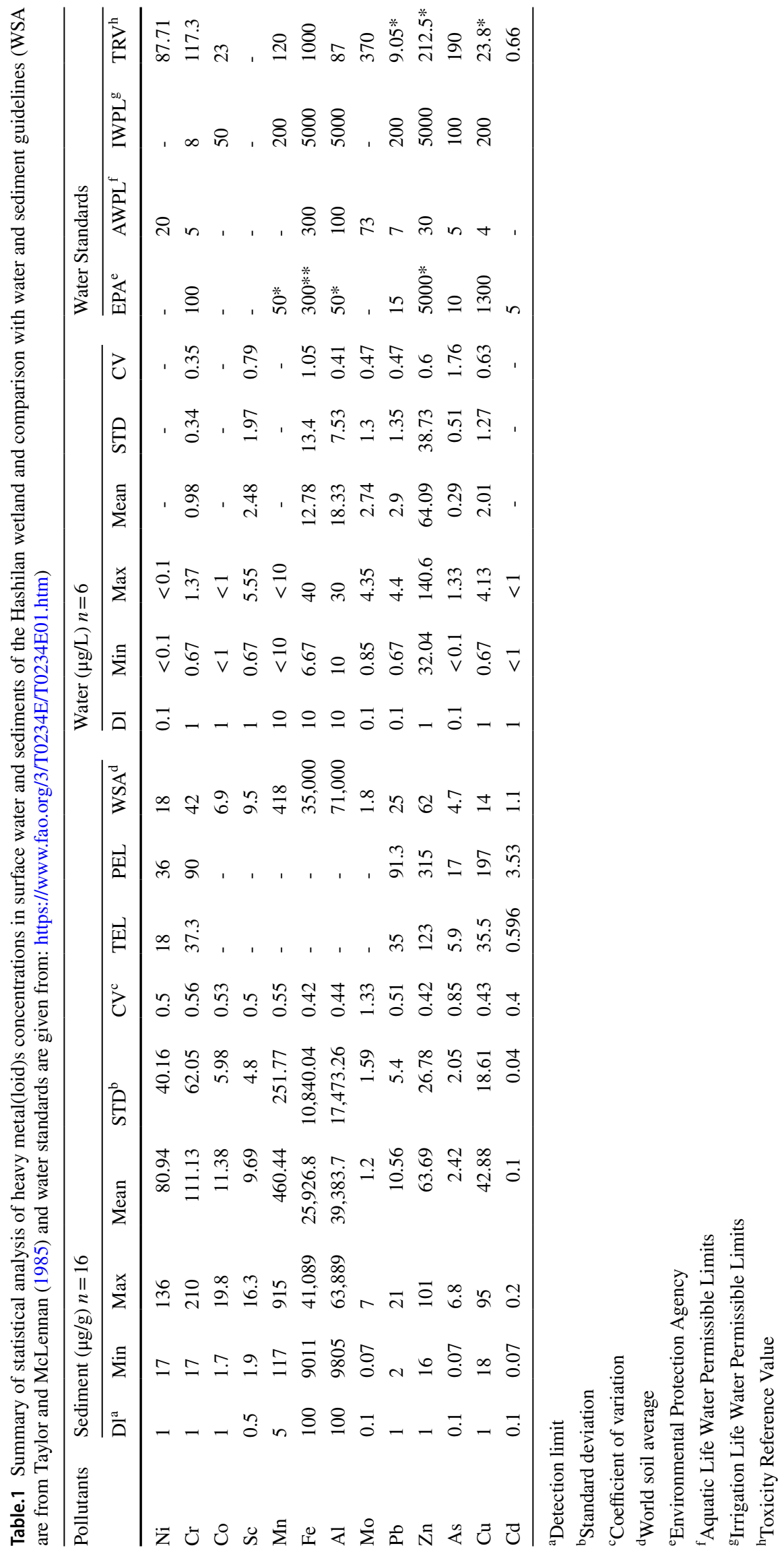


the assumption of equal variances is met (Table S2). Therefore, all soil and sediment samples were considered as a statistical population.

Based on the results, $\mathrm{Cu}$ and $\mathrm{Zn}$ concentrations ranged from 18 to $95 \mathrm{mg} / \mathrm{kg}$ and 16 to $101 \mathrm{mg} / \mathrm{kg}$, respectively. The elevated $\mathrm{Cu}$ contents were measured at stations $\mathrm{S} 1(95 \mathrm{mg} /$ $\mathrm{kg}$ ) and $\mathrm{S} 2(71 \mathrm{mg} / \mathrm{kg})$. Also, the higher $\mathrm{Zn}$ concentrations were belong to sites $\mathrm{S} 7(101 \mathrm{mg} / \mathrm{kg}), \mathrm{S} 1(92 \mathrm{mg} / \mathrm{kg})$ and $\mathrm{S} 2(85 \mathrm{mg} / \mathrm{kg})$. These stations have been located near the road, where agricultural machinery passes. The mean concentrations of these elements in the sediments of Hashilan wetland are higher than those reported from Shadegan wetland (Iran), Tijuana Estuary (California, USA), Nile delta (Egypt) and Sicily (Italy), but lower than those from Mangrove swamps (Hong Kong), Bellandur wetland (India), and Pearl River Estuary (China) (Table S3). The mean Cu value in the Hashilan wetland was about 3.06-fold higher than that in the world-soil average.

Nickel and Co concentrations varied from 17 to $136 \mathrm{mg} /$ $\mathrm{kg}$ and 1.7 to $19.8 \mathrm{mg} / \mathrm{kg}$, respectively. The higher $\mathrm{Ni}$ and $\mathrm{Co}$ values were observed at $\mathrm{S} 10$ (136 and $19.2 \mathrm{mg} / \mathrm{kg}$, respectively) and S7 (134 and $19.8 \mathrm{mg} / \mathrm{kg}$, respectively) sites. These stations are farmlands which are located near the road. The mean $\mathrm{Ni}$ and Co values (80.94 and $11.38 \mathrm{mg} / \mathrm{kg}$, respectively) in Hashilan wetland were about 4.5 -fold and 1.7 -fold higher than those in the world-soil average.

The average $\mathrm{Ni}$ value in comparison with its mean contents in other investigated regions was high. Also, the mean Co concentration was lower than that from Anzali wetland (Iran) and close to those of Sundarban (India) and Shadegan (Iran) wetlands (Table S3).

$\mathrm{Pb}, \mathrm{Mn}$ and $\mathrm{Al}$ contents varied from 2 to $21 \mathrm{mg} / \mathrm{kg}, 117$ to $915 \mathrm{mg} / \mathrm{kg}$, and 9805 to $63,889 \mathrm{mg} / \mathrm{kg}$, respectively. The highest mean values of these elements belonged to the S7 station. The mean $\mathrm{Pb}, \mathrm{Mn}$ and $\mathrm{Al}$ contents $(10.56,460.44$, and $39,383.7 \mathrm{mg} / \mathrm{kg}$, respectively) in the study area were below those of the world-soil average. However, the mean value of $\mathrm{Pb}$ in the sediments was higher than those from the Nile delta (Egypt), Mighan Wetland (Iran) and Sicily (Italia), but lower than other studies. Moreover, the mean Mn concentration in the study area illustrated a higher value than Shadegan wetland (Iran) and Sicily (Italia), but a lower value than Sundarban (India) and Sicily (Italia).

Arsenic concentration varied from 0.07 to $6.8 \mathrm{mg} / \mathrm{kg}$ with mean value of $2.42 \pm 2.05 \mathrm{mg} / \mathrm{kg}$. The elevated values of this element were observed at $S 9(6.8 \mathrm{mg} / \mathrm{kg})$ and $\mathrm{S} 7(5.9 \mathrm{mg} /$ $\mathrm{kg}$ ) stations. The average value of As in the study area was below those of the world-soil average and other investigated regions. Cr concentration varied from 17 to $210 \mathrm{mg} /$ $\mathrm{kg}$ with mean value of $111.13 \pm 62.05 \mathrm{mg} / \mathrm{kg}$. The higher Cr contents were observed at S1 (210 mg/kg), S7 (195 mg/ $\mathrm{kg})$ and $\mathrm{S} 9(190 \mathrm{mg} / \mathrm{kg})$ sites which have been located near the roads. Moreover, the average value of this element in
Hashilan wetland in comparison with its mean contents in other investigated regions was high and also it was about 2.6-fold higher than that in the world-soil average.

Molybdenum concentration ranged from 0.07 to $1 \mathrm{mg} /$ $\mathrm{kg}$ in all sampling sites except S3 station with $7 \mathrm{mg} / \mathrm{kg}$. The maximum Mo value in the Hashilan wetland was about 3.8fold higher than that in the world-soil average. Also, the range of $\mathrm{Cd}$ concentration was small, varying from 0.07 to $0.2 \mathrm{mg} / \mathrm{kg}$. The mean Cd content $(0.1 \mathrm{mg} / \mathrm{kg})$ in the study area was below that of the world-soil average. However, its mean value in the sediments was higher than those from Plateau lake wetland (China), Hengshuihu Wetland (China) and Nile delta (Egypt), but lower than other studies.

Totally, the average values of the investigated elements decrease as follows $\left(\mathrm{mg} \mathrm{kg}^{-1}\right): \mathrm{Al}(39,383.7)>\mathrm{Fe}$ $(25,926.8)>\mathrm{Mn}(460.4)>\mathrm{Cr}(111.12)>\mathrm{Ni}(80.94)>\mathrm{Zn}$ (63.7) $>\mathrm{Cu}(42.9)>\mathrm{Co}(11.4)>\mathrm{Pb}(9.7)>\mathrm{As}(2.4)>\mathrm{Mo}$ $(1.2)>\mathrm{Cd}(0.1)$. The coefficient of variation (C.V) is defined as the standard deviation to the mean ratio, which could reflect the degree of humankind effects (Guan et al. 2019; $\mathrm{Wu}$ et al. 2020). The coefficients of variation of As, $\mathrm{Cr}, \mathrm{Mn}$, $\mathrm{Co}, \mathrm{Ni}, \mathrm{Pb}, \mathrm{Sc}, \mathrm{Al}, \mathrm{Cu}, \mathrm{Fe}, \mathrm{Zn}$, and $\mathrm{Cd}$ were $85 \%, 56 \%, 55 \%$, $52 \%, 50 \%, 50 \%, 50 \%, 50 \%, 44 \%, 43 \%, 42 \%, 42 \%$, and $40 \%$, respectively. The variation degree of these elements was between 0.1 and 1, indicating moderate variability (Jin et al. 2019). While, the variation degree of Mo was greater than 1 , which is categorized as strong (Jin et al. 2019). The high coefficient of variation of Mo proposed that human activities could affect its value in the sediment of the wetland.

The elements of $\mathrm{Ni}, \mathrm{Mn}, \mathrm{Co}$, and $\mathrm{Cd}$ were not detectable in the surface water of Hashilan wetland, which caused the portions of these heavy metals to be negligible for water pollution. $\mathrm{Cr}$ and $\mathrm{Fe}$ elements were detectable at two or three sites. The elements of $\mathrm{Cu}$ and Mo contents ranged from 0.7 to $4.13 \mu \mathrm{g} / \mathrm{L}$, and 0.85 to $4.35 \mu \mathrm{g} / \mathrm{L}$, respectively. The higher values of $\mathrm{Cu}$ and Mo were observed at S3, S8, and S12 sites where the pollutants values increase due to stagnant water. Phosphate fertilizers, pesticides or fungicides contain $\mathrm{Cu}$ and Mo elements which could be the source of these elements at S8 (the outlet of agricultural wastewater into the wetland) (Li et al. 2020). Also, wear dust from brake linings and tires of vehicles can be considered the source of these elements at S3 (near the road) (Lin et al. 2015). Zinc value varied from 32.04 to $59.13 \mu \mathrm{g} / \mathrm{L}$ in all sampling sites except the $\mathrm{S} 8$ station with $140.58 \mu \mathrm{g} / \mathrm{L}$ where agricultural runoff entered the wetland. Lead concentration ranged from 0.67 to $4.4 \mu \mathrm{g} / \mathrm{L}$ with a mean value of $2.9 \mu \mathrm{g} / \mathrm{L}$. The higher $\mathrm{Pb}$ contents were observed at S2 $(4.4 \mu \mathrm{g} / \mathrm{L}), \mathrm{S} 8(3.79 \mu \mathrm{g} / \mathrm{L})$ and $\mathrm{S} 1(3.64 \mu \mathrm{g} / \mathrm{L})$ sites. Aluminum and Sc concentrations ranged from 10 to $30 \mu \mathrm{g} / \mathrm{L}$ and 0.67 to $5.55 \mu \mathrm{g} / \mathrm{L}$, respectively. The highest contents of these elements were measured at stations S12 and S8, respectively. Also, As values were only detected at S8 and S12 stations. Totally, the average 
values of the investigated elements decrease as follows ( $\mu \mathrm{g}$ $\left.1^{-1}\right): \mathrm{Zn}(64.09)>\mathrm{Al}(18.33)>\mathrm{Fe}(12.78)>\mathrm{Pb}(2.9)>\mathrm{Mo}$ (2.74) $>\mathrm{Sc}(2.48)>\mathrm{Cu}(2.01)>\mathrm{Cr}(0.98)>\mathrm{As}(0.29)$. The concentrations of the investigated metal(loid)s were below the recommended drinking water standards by EPA (USEPA 2012) and WHO (2017).

\section{Assessment of PTEs contamination}

\section{Sediment quality assessment}

Geoaccumulation index (Igeo) The calculated $\mathrm{I}_{\text {geo }}$ values for PTEs in sediments of the Hashilan wetland are presented in Fig. S1. Lead, Cd, As, Fe, and $\mathrm{Al}$ in the Hashilan sediments were classified as "unpolluted" status as a result of the $\mathrm{I}_{\text {geo }}$ index lower than Zero, while the $\mathrm{I}_{\text {geo }}$ values of $\mathrm{Sc}, \mathrm{Co}, \mathrm{Mn}$, and $\mathrm{Zn}$ fluctuated from "unpolluted" to "unpolluted to moderately polluted" status. Comparatively, the $I_{\text {geo }}$ values for $\mathrm{Cu}$ and $\mathrm{Ni}$ varied from -0.22 to 2.18 and -0.67 to 2.33 , respectively, suggesting "no contamination" to "moderate to strong contamination." Chromium in sediments was classified as no pollution to moderate pollution. The $\mathrm{I}_{\text {geo }}$ values for Mo showed an "unpolluted" status at all sampling sites except S3, which presented moderate pollution. Totally, the average $\mathrm{I}_{\text {geo }}$ values of the investigated metal(loid)s were as follows: Cd (-4.10), As (-2.64), Pb (-2.06), Mo (-1.99), Al (-1.63), $\mathrm{Fe}(-1.16)$, Sc (-0.81), Zn (-0.72), Mn (-0.69), Co (-0.16), $\mathrm{Cr}$ (0.48), $\mathrm{Cu}(0.92)$, and $\mathrm{Ni}$ (1.34), proposing the tested metal(loid)s except $\mathrm{Ni}, \mathrm{Cr}$, and $\mathrm{Cu}$ indicated no pollution in general. Also, the average contents of $\mathrm{I}_{\text {geo }}$ for $\mathrm{Ni}$ indicated moderate pollution, while those of $\mathrm{Cr}$ and $\mathrm{Cu}$ demonstrated uncontaminated to moderately contaminated conditions.

Enrichment factor (EF) The calculated EF values for PTEs in sediments of the Hashilan wetland are presented in Fig. S2 (SI 2). The EFs values calculated revealed that $\mathrm{Al}, \mathrm{As}, \mathrm{Cd}$, $\mathrm{Co}, \mathrm{Mn}, \mathrm{Pb}, \mathrm{Sc}$, and $\mathrm{Zn}$ were minimal enriched at all sampling sites, which indicate that the mentioned elements were mainly originated from crustal materials or natural weathering. Also, the sediments were moderately enriched with $\mathrm{Ni}$ at all stations. Enrichment factors of $\mathrm{Cr}$ were also higher or much closer to 2 in all the sampling sites, indicating the influence of anthropogenic pollution in sediments. According to studies conducted in Iran, the chromium and nickel concentrations in the soil of Iran country (especially near the Zagros mountains) are higher than those of the global average of soil and upper crust (Abbasi et al. 2018, 2019). Despite moderate $\mathrm{EFs}$ of $\mathrm{Ni}$ and $\mathrm{Cr}$, these elements showed low and uniform EF ranges which illustrate a geogenic source. Ophiolite sequences of the Zagros fold-and-thrust belt are associated with high levels of toxic trace elements, particularly nickel, chromium, and cobalt. Therefore, soils formed over them are polluted by the mentioned metals were controlled by weathering processes of parent materials (Allahyari et al. 2010; Namaghi et al. 2011).

Mo showed significant and moderate enrichments at S3 and (S5 and S6) stations, respectively, while other stations were relatively unpolluted. Copper $(\mathrm{Cu})$ revealed significant and moderate enrichments at (S5, S6) and (S9, S10 and S13) stations, respectively, while other stations indicated deficiency to minor enrichments. Therefore, the anthropogenic sources are suggested for $\mathrm{Cu}$, and $\mathrm{Mo}$ at some stations. Totally, the mean EFs of trace elements were ranked as follows: $\mathrm{Ni}(4.44)>\mathrm{Cu}(3.8)>\mathrm{Cr}(2.5)>\mathrm{Co}$ (1.6) $>\mathrm{Mn}(1.14)>\mathrm{Zn}(1.08)>\mathrm{Mo}(1.04)>\mathrm{Fe}(0.81)>\mathrm{Al}$ $(0.57)>\mathrm{As}(0.45)>\mathrm{Pb}(0.44)>\mathrm{Cd}(0.13)$, suggesting the tested metal(loid)s except $\mathrm{Ni}, \mathrm{Cu}$, and $\mathrm{Cr}$ illustrated minimum enrichment in general. While, the average contents of $\mathrm{EFs}$ for $\mathrm{Ni}, \mathrm{Cu}$, and $\mathrm{Cr}$ indicated moderate enrichment.

Contamination factor (CF) The calculated CF values for PTEs in sediments of the Hashilan wetland are presented in Fig. S3. Contamination factor $(\mathrm{CF})$ values calculated showed that all the sediment samples have been low contaminated by $\mathrm{Al}, \mathrm{Cd}, \mathrm{Pb}$, and Mo elements. Also, As revealed minor contamination for all sampling sites except $\mathrm{S} 7$ and $\mathrm{S} 9$ which were moderately polluted. Zinc and Co showed a moderate degree of pollution at most stations. Chromium illustrated low, moderate, and considerable contaminations at (S5, S6, S8), (S3, S4, S11, S15, S16) and other stations, respectively. Moreover, serious contamination of $\mathrm{Ni}$ was observed at S1, S7, S9, and S10 stations, also half of the stations were considerably polluted by this heavy metal. Copper showed serious contamination at the $\mathrm{S} 1$ station, while moderate to considerable contaminations of $\mathrm{Cu}$ were observed for other sampling sites. Manganese, $\mathrm{Sc}$, and Fe showed low to moderate contaminations in the Hashilan sediments. The mean CFs of trace elements were ordered as follows: $\mathrm{Ni}(4.5)>\mathrm{Cu}$ (3.1) $>\mathrm{Cr}(2.64)>\mathrm{Co}(1.65)>\mathrm{Mn}(1.1)>\mathrm{Zn}(1.03)>\mathrm{Sc}$ (1.02) $>\mathrm{Fe}(0.74)>\mathrm{Mo}(0.67)>\mathrm{Al}(0.55)>\mathrm{As}(0.51)>\mathrm{Pb}$ $(0.42)>\mathrm{Cd}(0.09)$, suggesting the investigated metal(loid) s except $\mathrm{Ni}, \mathrm{Cu}, \mathrm{Cr}, \mathrm{Co}, \mathrm{Mn}, \mathrm{Zn}$, and Sc demonstrated low contamination in general. While, the mean contents of $\mathrm{CFs}$ for $(\mathrm{Ni}, \mathrm{Cu})$, and $(\mathrm{Cr}, \mathrm{Co}, \mathrm{Mn}, \mathrm{Zn}, \mathrm{Sc})$ showed considerable and moderate pollutions, respectively.

Modified pollution index (MPI) and Nemerow pollution index (NPI) According to Table S4 and Fig. S4, MPI (modified pollution index) revealed that S5 and S6 sites have been severely polluted, while other sampling stations except S14 were moderately heavily polluted. Also, the site of S14 indicated moderate pollution.

NPI (pollution index) indicated S1, S2, S4, S7, S9, S10, $\mathrm{S} 12, \mathrm{~S} 13$, and S14 sites were heavily polluted, and the rest 
sampling stations have been severe to moderately polluted. It seems that NPI has overestimated the pollution degree at the sampling sites compared to MPI, which is computed by the enrichment factor (Fig. S4).

\section{Water quality assessment}

Heavy metal toxicity load (HMTL) To evaluate the HMTL, the potentially toxic metal(loid)s including $\mathrm{As}, \mathrm{Cu}, \mathrm{Pb}, \mathrm{Zn}$, $\mathrm{Cr}$, and $\mathrm{Al}$ were chosen from the ATSDR substance priority list (ATSDR 2017). Also, different guidelines including aquatic life water permissible limits (AWPL) (CCME 2007), toxicity reference values (TRVs) (WSRC 1999) and recommended drinking water standards by the environmental protection agency (EPA) (USEPA 2012) were used to assess different permissible toxicity loads. In the study area, HMTL ranged from 55.35 to $153.56 \mathrm{mg} / \mathrm{L}$ with an average of $78.48 \mathrm{mg} / \mathrm{L}$. The HTML calculated was less than the permissible toxicity loads prepared by EPA and TRV guidelines (5774. 8 and $966.5 \mathrm{mg} / \mathrm{L}$, respectively), suggesting low pollution of PTEs at all sampling sites, while HTML of the $\mathrm{S} 8$ station $(153.56 \mathrm{mg} / \mathrm{L})$ was above the permissible toxicity load prepared by AWPL guideline $(119.1 \mathrm{mg} / \mathrm{L})$ (Table 2). However, the pollution loads of $\mathrm{Cu}$ at $\mathrm{S} 3, \mathrm{Cr}$ at $\mathrm{S} 1, \mathrm{~S} 2, \mathrm{~S} 8$ and $\mathrm{Zn}$ at all monitored stations were above their corresponding permissible toxicity loads prepared by AWPL guideline, proposing the reduction of $\mathrm{Zn}, \mathrm{Cr}$, and $\mathrm{Cu}$ contents of the Hashilan water. However, this study has evaluated the water quality with respect to some heavy metals, while other organic and inorganic pollutants listed in the ATSDR substance priority list could be considered to obtain a better insight into the water quality of the study area.

Nemerow pollution index (NPI) To evaluate the Nemerow pollution index, reference values were selected from AWPL, TRVs and EPA guidelines to provide more accurate information about the pollution rate in the surface water.

The single factor index values of $\mathrm{Zn}$ at all stations, and $\mathrm{Cr}$ at S1, S2, S8 sites calculated by AWPL as a reference value exceeded 1 which caused NPI $>1$ at all stations, representing serious pollution of metal(loid)s at all monitoring sites (Fig. S5). The highest NPI value was 3.41, which was detected at the $\mathrm{S} 8$ station. However, $\mathrm{Zn}$ and $\mathrm{Cr}$ were considered to be the significant factors for NPI $>1$. In comparison, the single factor index values of the investigated PTEs calculated by EPA and TRV guidelines as the reference values were below 1 which caused NPI $<1$ at all sampling sites, showing no pollution threat at all stations (Fig. S5). The results indicated the pollution rate of water could be dependent on the selected reference values. However, agricultural activities have affected the aquatic environment of the Hashilan wetland. Therefore, to protect the wetland environment, the pollution rate is required to be controlled.

Mean-PEL-quotient The comparison between sediment quality guidelines and metal concentrations in sediment is applied to evaluate the contamination effects on the biota (Maanan et al. 2015). Copper values at most stations except S8 were above the respective TEL content; even though, its

Table.2 Heavy metal toxicity load of the surface water based on relative toxicity level of heavy metal(loid)s

\begin{tabular}{|c|c|c|c|c|c|c|c|}
\hline \multicolumn{8}{|l|}{ Toxicity of heavy metals (mg/L) } \\
\hline Sampling sites & $\mathrm{Cu}$ & $\mathrm{Pb}$ & $\mathrm{Zn}$ & As & $\mathrm{Cr}$ & $\mathrm{Al}$ & $\begin{array}{l}\text { Heavy metal toxicity } \\
\text { load (HTML) (mg/L) }\end{array}$ \\
\hline $\mathrm{S} 1$ & 1.30 & 5.57 & 53.99 & 0.11 & 1.13 & 6.85 & 68.96 \\
\hline $\mathrm{S} 2$ & 0.85 & 6.74 & 53.03 & 0.11 & 1.10 & 6.85 & 68.67 \\
\hline $\mathrm{S} 3$ & 3.32 & 1.03 & 43.33 & 0.11 & 0.60 & 13.70 & 62.09 \\
\hline S5 & 0.54 & 4.19 & 43.14 & 0.11 & 0.60 & 13.70 & 62.28 \\
\hline S8 & 2.25 & 5.80 & 128.35 & 2.23 & 1.22 & 13.70 & 153.56 \\
\hline S12 & 1.46 & 3.28 & 29.25 & 0.22 & 0.60 & 20.55 & 55.35 \\
\hline Total & 9.72 & 26.61 & 351.09 & 2.89 & 5.24 & 75.35 & \\
\hline Hazard Intensity Score ${ }^{*}$ & 805 & 1531 & 913 & 1676 & 893 & 685 & \\
\hline Permissible toxicity load (EPA) ${ }^{a}$ & 1046.50 & 22.97 & 4565.00 & 16.76 & 89.30 & 34.25 & 5774.80 \\
\hline Permissible toxicity load (TRV) ${ }^{b}$ & 18.58 & 13.86 & 194.01 & 318.44 & 362.02 & 59.60 & 966.50 \\
\hline Permissible toxicity load (AWPL) ${ }^{c}$ & 3.22 & 10.72 & 27.39 & 8.38 & 0.89 & 68.50 & 119.10 \\
\hline
\end{tabular}

*ATSDR 2017

${ }^{a}$ Environmental Protection Agency

${ }^{\mathrm{b}}$ Toxicity Reference Value

${ }^{\mathrm{c}}$ Aquatic Life Water Permissible Limits

Ecological risk assessment for heavy metal(loid)s in sediments 
concentrations were lower than the respective PEL value. Nickel concentrations were above the respective PEL value at all sampling sites except S5, S6, and S8 stations which could create potential adverse biological consequences at these sites. In the case of $\mathrm{Cr}$, its contents exceeded the respective PEL value at $\mathrm{S} 1, \mathrm{~S} 7$, and $\mathrm{S} 9$ sites which could cause potential adverse ecological risk at the mentioned stations, while its maximum values at S5, S6, and S8 stations were lower than the respective TEL content. Moreover, the $\mathrm{As}, \mathrm{Cd}, \mathrm{Pb}$, and $\mathrm{Zn}$ values in all sediment samples were observed to be below the respective TEL contents, proposing that these elements in Hashilan wetland would not be associated with adverse ecological risk.

However, the mean PEL quotients were between 0.11 and 1.5 at all sampling sites, representing low to moderate ecological risk for an aquatic organism, with a toxicity occurrence of between 10 and $25 \%$.

RI and MRI The highest and lowest values of $\mathrm{Er}_{\mathrm{i}}$ in sediments of the Hashilan wetland were belong to $\mathrm{Cu}$ and As elements, respectively. The rest of the heavy metals were observed in between the two extremes. Computed $\mathrm{Er}_{\mathrm{i}}$ with enrichment factor indicated a moderate risk of $\mathrm{Cu}$ at the only $\mathrm{S} 5$ site, while other elements exhibited low risk at all locations. Computed $\mathrm{Er}_{\mathrm{i}}$ with contamination factor in comparison with $\mathrm{Er}_{\mathrm{i}}$ with enrichment factor showed that the ecological risk of $\mathrm{Cu}$ has decreased to low risk at S5 station. Furthermore, all the heavy metal(loid)s presented low risk at all sites.

MRI (modified ecological risk index), which is calculated by enrichment factor, exhibited low ecological risk at all sampling stations. Also, according to RI (potential ecological risk index), which is calculated by contamination factor, all stations caused low ecological risk for ecosystem (Fig. S6 and Table S4).

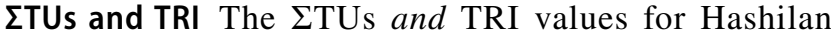
sampling sites are demonstrated in Fig. S7 and Fig. S8, respectively. The $\Sigma$ TUs values for all sediment samples varied from 0.8 to 5.52. Based on the $\Sigma$ TUs results, five sampling sites demonstrated moderate toxicity risk due to $\Sigma$ TUs values greater than 4.0 , while other sampling sites indicated low toxicity to the ecosystem. According to the contributing mean ratios of the metal/loids toxic units (TUs) in all sediment samples to $\Sigma$ TUs, Ni $(54.72 \pm 5.20 \%), \mathrm{Cr}$ $(19.16 \pm 3.73 \%)$, and $\mathrm{Cu}(13.66 \pm 6.46 \%)$ presented higher potential toxicity compared to the $\mathrm{Zn}(7.16 \pm 0.95 \%), \mathrm{Pb}$ $(2.85 \pm 0.89 \%)$ As $(1.5 \pm 1.07 \%)$, and Cd $(0.97 \pm 0.74 \%)$. Also, TRI values ranged from 2.45 to 15.95 , with the highest value at $\mathrm{S} 1$ and the lowest at $\mathrm{S} 6$, which was consistent with the $\Sigma$ TUs contents. Compared with the $\Sigma$ TU contents, 2 stations ( $\mathrm{S} 1$ and $\mathrm{S} 7$ ) indicated considerable toxicity risk with the TRI values greater than 15 . Also, seven stations exhibited moderate toxicity risk with the TRI values varying from 10 to 15 . Meanwhile, low toxic risk was measured at 4 stations with TRI values varying from 5 to 10 . Three stations also showed no toxic risk with TRI values lower than 5 . However, the areas with higher potential risk were mainly focused in the vicinity of roads.

The mean contribution ratios of each metal(loid) to the TRI contents were $54.78 \pm 6.43 \%$ for $\mathrm{Ni}, 19.44 \pm 8.27 \%$ for $\mathrm{Cu}, 15.24 \pm 3.25 \%$ for $\mathrm{Cr}, 4.23 \pm 0.56 \%$ for $\mathrm{Zn}, 2.7 \pm 0.85 \%$ for $\mathrm{Pb}, 2.18 \pm 1.55 \%$ for As, and $1.44 \pm 1.03 \%$ for $\mathrm{Cd}$. Moreover, compared with the ratio of $\mathrm{Cu}, \mathrm{As}$, and $\mathrm{Cd}$ in the $\Sigma$ TUs, the contributing ratio of the mentioned elements was increased according to the TRI, proposing higher potential toxicity of the mentioned elements. $\mathrm{Cu}$ and $\mathrm{Zn}$ showed a lower toxicity contribution in the TRI compared to the $\Sigma T$ Ts. In addition, according to $\Sigma T U$ and TRI contents, the highest contribution ratio has belonged to the $\mathrm{Ni}$ element.

According to the results, the $\Sigma$ TUs method demonstrated the lower potential toxicity risk compared to the TRI method because the TRI index applied the TEL and PEL values, providing more reference contents compared to the $\Sigma$ TUs, which only consider high PEL values for toxicity risk estimation (Ji et al. 2019a).

It is worthy to note that several methods of risk evaluation utilize different toxicity parameters or values of PTEs, which cause different index contents or risk levels. Among the MRI, RI, TRI, Mean-PEL-quotient, and TUs methods, TRI equation better presented the toxicity risk of heavy metals regarding the results of MPI and PI indices. However, the risk level of Mean-PEL-quotient is higher than that of the MRI and RI methods. Totally, TRI index is more suitable for the PTEs risk assessment in the sediments of Hashilan wetland.

\section{Ecological risk assessment for heavy metals in water}

Water quality guidelines of heavy metals for the protection of aquatic Life and agriculture proposed by the Canadian Council of Ministers of the Environment (CCME 2007) were used as the water quality reference values due to the agricultural activities and existence of unique species in the Hashilan wetland. Also, another reference value called TRVs (WSRC 1999) was used to evaluate the ecological risk of Hashilan water.

The ecological risk index calculated by three reference values including aquatic life water permissible limits (AWPL), irrigation life water permissible limits (IWPL) and aquatic toxicity reference values (TRVs) ranged from 5.8 to 16.3 with a mean of $9.25,0.27$ to 0.67 with mean of 0.41 , and 1.4 to 3.4 with mean of 2.36 , respectively (Fig. S9). The RI results indicated a low ecological risk for all sampling sites. With respect to the single metal risk index, the ecological risk of all the investigated PTEs in surface water was low. 


\section{Source identification of heavy metals in the sediments}

\section{Correlation analysis}

The Spearman correlation coefficients among trace metal/ metalloids and those between metals and physiochemical parameters in the sediment system are illustrated in Table S5. These relationships could be applied to determine PTEs sources (Ji et al. 2019b; Xiao et al. 2019). Also, the mobility and bioavailability of heavy metals in sediments could be affected by sediment properties like organic matter, particle composition, EC and pH (Gao et al. 2016).

Particle size can modify the distribution and adsorption behavior, erosion and remobilization of heavy metals (Huang et al. 2020). Among different particles, fine grains tend to absorb more heavy metals by providing a high specific surface area and binding sites (Gao et al. 2016; Hu et al. 2018). According to the correlation coefficients, silt particles were weakly correlated with the studied elements, while clay particles illustrated positive correlation with $\mathrm{Ni}$, $\mathrm{Al}, \mathrm{Fe}, \mathrm{Sc}(p<0.01, r=0.7)$; $\mathrm{Co}(p<0.01, r=0.6)$; $\mathrm{Cr}, \mathrm{Pb}$, $\mathrm{Zn}(p<0.05, r=0.5)$ which indicate the mentioned metals tend to accompany with the proportion of clay. However, only a negative correlation was found between clay particles and Mo $(p<0.05, r=-0.5)$. Also, sand particles were negatively correlated with the investigated PTEs except for Mo, suggesting these heavy metal(loid)s could be easily released from the sand grains (Yavar Ashayeri and Keshavarzi 2019; Khalil and El-Gharabawy 2016).

Organic matter as a significant sink tends to create complexes with metals via providing certain ligands (Gao et al. 2016; Zhu et al. 2017). However, OM was negatively correlated with $\mathrm{Co}, \mathrm{Fe}(p<0.01 ; r=-0.8) ; \mathrm{As}, \mathrm{Ni}, \mathrm{Al}, \mathrm{Cr}$, Sc $(p<0.01 ; r=-0.7)$, and $\mathrm{Pb}, \mathrm{Zn}(p<0.01 ; r=-0.6)$, indicating distribution and adsorption of the investigated elements has been less affected by organic matter compared to the other influential factors and adsorbents. Organic matter $(\mathrm{OM})$ showed a significant positive correlation with sand $(p<0.05 ; r=0.5)$. The higher contents of organic matter were found at the stations in which agricultural wastewater enters the wetland because not only agricultural runoff contains high values of organic matter (Zhu et al. 2017) but also dense vegetation is observed at these situations. At the mentioned stations, as the runoff enters the wetland, the flow velocity of agricultural runoff decreases which causes the coarse particles to be firstly deposited in these positions. Therefore, the association of sand particles and organic matter is observed in these stations which causes a strong correlation between them. Molybdenum also had a positive correlation with OM and sand particles. Such correlations could be related to the same origin or transport path for them (Liu et al. 2019). Also, this heavy metal indicated a weakly positive correlation with $\mathrm{Cu}$, while no correlation was found between Mo and other elements, suggesting their concentrations may be controlled via different sources which cause the distributional difference between them (Suresh et al. 2012; Yuanan et al. 2020). A significant correlation was not found among cation exchange capacity (CEC) and other elements and parameters, and only a weakly positive correlation was observed between CEC and clay particles. Most studies emphasize the CEC value depends on clay particles and organic matter, while the elemental composition of clay particles must be mentioned (Malcolm and Kennedy 1970). Also, CEC values of greater particles size could be higher than clay particles, depending on parent material, age and degree of weathering, type of clay minerals, climatic factors, and physical and chemical dispersion (Malcolm and Kennedy 1970). Therefore, in order to understand the controlling factors of CEC parameters, the mineralogy of particles, type of organic matter and other effective parameters should be studied.

Spatial distribution patterns, transfer and mobility of PTEs could be affected by Fe/Mn oxides (Ji et al. 2019b). However, $\mathrm{Fe}$ and $\mathrm{Mn}$ were significantly correlated with the studies elements except As, Cd and Mo in sediments. Nickel, $\mathrm{Pb}, \mathrm{Zn}, \mathrm{Cr}, \mathrm{Co}, \mathrm{As}$, and $\mathrm{Sc}$ revealed a significant positive correlation with each other $(r>0.6)$. Copper also showed a positive correlation with As, while this heavy metal was significantly and positively correlated with the mentioned elements, which indicate the same source probably and/or similar geochemical behaviors for the mentioned PTEs (Suresh et al. 2012; Xiao et al. 2019; Zhu et al. 2017). However, Sc is an immobile metal that originated from lithologic sources (Li et al. 2020), showing the parent rock has impressed the contents of metal(loid)s associated with Sc. Cadmium illustrated no significant relationship with metal(loid)s and parameters, and only a weakly positive correlation was observed among this heavy metal and $\mathrm{Cu}, \mathrm{Pb}, \mathrm{Zn}, \mathrm{Ni}$, and $\operatorname{Cr}(P>0.05 ; r=0.3)$. These results may be due to the similar values and limited fluctuations of $\mathrm{Cd}$ concentrations at most sampling sites.

The mobility of elements could also be controlled by sediment pH (Fei et al. 2019; Ustaoğlu and Islam 2020). In the study area, sediment's $\mathrm{pH}$ was weakly correlated with the investigated metals as a result of the limited variability and alkaline status of $\mathrm{pH}$ values.

\section{Principal component analysis (PCA)}

Principal component analysis was firstly employed for identifying the potential contamination sources of PTEs. The measured KMO value and significance level of Bartlett's Sphericity test were 0.7 and $0(<0.05)$, respectively, indicating the suitability of data for performing PCA analysis. Kaiser's rule was utilized to specify the components extracted 
from the variables. The factor loadings $>0.75,0.75-0.5$ and 0.5-0.3 are defined as "strong", "moderate" and "weak", respectively (Zeng et al. 2019; Zhang et al. 2020). Table 3 illustrated the factor loadings of the studied PTEs at the extracted components.

The PCA performance identified two varimax rotated factors with eigenvalues greater than 1 and accounting for $81.62 \%$ of the total variance. The first principal component (PC1) accounted for $69.75 \%$ of the total contribution with high $\mathrm{Pb}, \mathrm{Zn}, \mathrm{Ni}, \mathrm{Co}, \mathrm{As}, \mathrm{Mn}, \mathrm{Cr}, \mathrm{Al} \mathrm{Sc}, \mathrm{Fe}$ loadings and moderate $\mathrm{Cu}$ and weak $\mathrm{Cd}$ weights, which is in agreement with the results of the correlation analysis.

Based on the EF assessment, the mentioned elements except $\mathrm{Ni}$ and $\mathrm{Cr}$ exhibited depletion or minor enrichment in the sediments. Since the $\mathrm{Ni}$ and $\mathrm{Cr}$ contents in soils mainly depend on their concentrations in parent rocks, and human inputs of $\mathrm{Ni}$ and $\mathrm{Cr}$ from manure, limestone, and fertilizers are generally less than their background values in soils (Lv 2019), these heavy metals have been moderately enriched due to the geogenic source. Totally, a natural source (parent rock materials) could be attributed to this component due to the presence of lithogenic elements such as $\mathrm{Fe}, \mathrm{Sc}, \mathrm{Mn}$, and $\mathrm{Al}$ in PC1 (Qiutong and Mingkui 2017; Zhu et al. 2019).

PC2, with $10.25 \%$ of the total variance and 1.18 of the Eigen value, indicated a high weight of Mo, moderate $\mathrm{Cu}$ loading and weak $\mathrm{Cd}$ weight. According to the $\mathrm{EF}$ values, $\mathrm{Mo}$ and $\mathrm{Cu}$ demonstrated middle to extreme enrichments at some stations. Also, wide and skewness EF values were observed for $\mathrm{Mo}$ and $\mathrm{Cu}$. Phosphate fertilizers, which are used in croplands, contain some metals such as $\mathrm{Cu}$, and $\mathrm{Mo}$

Table.3 The rotated factor pattern derived from PCA for the contents of heavy metal(loid)s in the sediments of Hashilan wetland
(Azzi et al. 2017; Gupta et al. 2014). Also, Cu is extensively utilized as a significant metal for pesticides or fungicides (Li et al. 2020; Liang et al. 2017). On the other hand, wear dust from brake linings and tires of vehicles and agricultural machinery can be a source for the release of these elements into the environment (Lin et al. 2015). Thus, this factor is related to both natural sources and agricultural activities.

Copper on two principal components showed moderate loading, which suggested two sources of principal components (natural, and mixed sources) could be considered for this metal. Moreover, $\mathrm{Cd}$ metal showed ambiguous attribution and weak load on two principal components. The correlation analysis illustrated this element has no significant correlation with other elements. Also, the Cd concentrations were evaluated low and uniform, suggesting this heavy metal was derived from lithogenic origins.

Then, the percent contribution of each component was assessed by multiple linear regression via performing a stepwise procedure. Two principal component scores including natural and mixed sources were regressed against the investigated metal(loid)s. The obtained equation is presented as:

$\mathrm{Z}=0.981 \mathrm{PC} 1+0.057 \mathrm{PC} 2\left(\mathrm{R}^{2}=0.96\right)$

Then, the regression coefficients detected were applied to estimate the portion of each source, presented by principal components. Based on the results, the contribution of natural sources was $94.51 \%$ of the total portions and the mixed sources containing geological origin and agricultural activities (fertilizers and agricultural equipment) contributed 5.5\% of the total shares.

Although the contribution rates of two sources were specified, the PTEs portions in each source could not be achieved due to negative values detected in component scores derived from the APCS-MLR model (Dong et al. 2019).

\section{Positive matrix factorization model}

To verify the extracted sources of PCA analysis, the PMF model was employed not only to recognize the sources of heavy metals but also to quantify the metal(loid)s contributions in sediments (Dong et al. 2019; Yuanan et al. 2020).

The PMF model run was 20 times and the seed number was randomly selected. To detect the minimum $\mathrm{Q}$ value and the optimal number of origins, two to five factors were tested. The lowest and stable amount of Q was achieved when the factors extracted were three (Fig. 2). Also, the signal-to-noise ratios $(\mathrm{S} / \mathrm{N})$ of the investigated metal(loid)s were higher than 1 , indicating the data qualities are strong (Mao et al. 2020; Wu et al. 2020).

Also, the scaled residuals of sediment samples illustrated a normal distribution between -3.0 and 3.0. Moreover, $\mathrm{Q}_{\text {robust }} / \mathrm{Q}_{\text {true }}$ ratio was 0.96 and $\mathrm{R}^{2}$ between the predicted
Bold figures indicating high positive correlation of initial variables to rotated fact 
Fig. 2 Results of PMF source apportionment modeling for heavy metal(loid)s in the sediments of Hashilan wetland
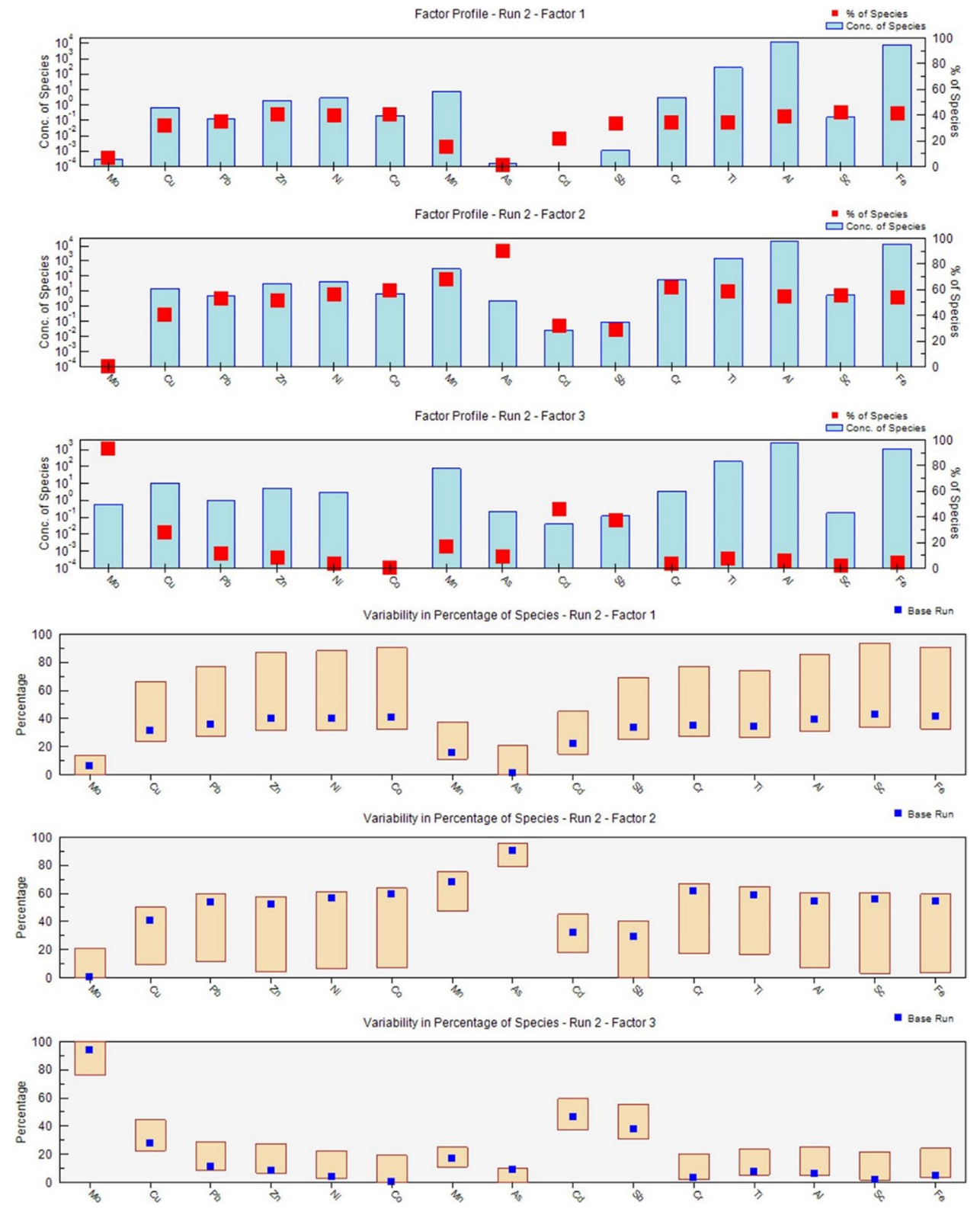

and measured values of all metal(loid)s was greater than 0.6 , proposing the factors extracted by the PMF model are reliable (Fig. 2). The validity of PMF results was estimated via the performance of 80 bootstrap runs with a minimum $R^{2}$ value of 0.6 .

According to Fig. 3, Factor 1 (F1) was dominated by Sc $(42 \%), \mathrm{Fe}(41 \%), \mathrm{Co}(41 \%), \mathrm{Ni}(40 \%), \mathrm{Zn}(40 \%), \mathrm{Al}$ (39\%), $\mathrm{Pb}(36 \%), \mathrm{Cr}(35 \%), \mathrm{Cu}(32 \%)$, followed by $\mathrm{Mn}$ (15\%), Cd (12\%), Mo (6\%) and As (1\%). The metal(loid) $\mathrm{s}$ in Factor 1 were again categorized into a group (Factor 2) for PMF, which was presented by As (80\%), Mn (68\%), $\mathrm{Ni}(67 \%), \mathrm{Cr}(61 \%), \mathrm{Co}(59 \%), \mathrm{Sc}(56 \%), \mathrm{Al}=\mathrm{Fe}(55 \%)$, $\mathrm{Pb}=\mathrm{Zn}(52 \%), \mathrm{Cu}(41 \%)$, and $\mathrm{Cd}(32 \%)$. As mentioned, As and Mn elements showed natural sources based on the $\mathrm{EF}$ and $\mathrm{I}_{\text {geo }}$ equations. However, higher percentages of these elements in F2 compared to the F1 may be related to a high $\mathrm{CV}$ of their concentrations. According to various researches, the concentrations of $\mathrm{Fe}, \mathrm{Al}, \mathrm{Sc}, \mathrm{Mn}, \mathrm{Cr}$, and $\mathrm{Ni}$ are controlled by parent materials (Dong et al. 2019; Liang et al. 2017; Lu et al. 2020). These two factors, similar to factor 1 of the PCA model, propose the mentioned metal(loid)s were released from natural weathering of rock materials (Harikrishnan et al. 2017).

Factor 3 indicated high weights of Mo (94\%), Cd (46\%), and $\mathrm{Cu}(27 \%)$, while its contributions to $\mathrm{Mn}(17 \%), \mathrm{Pb}$ (12\%), As (9\%), Zn (8\%), Al (6\%), $\mathrm{Cr}=\mathrm{Fe}(4 \%), \mathrm{Ni}(3 \%)$, and $\mathrm{Sc}(2 \%)$ were relatively low. As mentioned, EF values of $\mathrm{Mo}$ and $\mathrm{Cu}$ were middle to extreme at some stations. Also, $\mathrm{Mo}$ and $\mathrm{Cu}$ are found in fertilizers, manures and other agricultural activities (Azzi et al. 2017). Thus, this 
Fig. 3 Contribution of the heavy metal(loid)s according to factor profiles obtained by PMF model

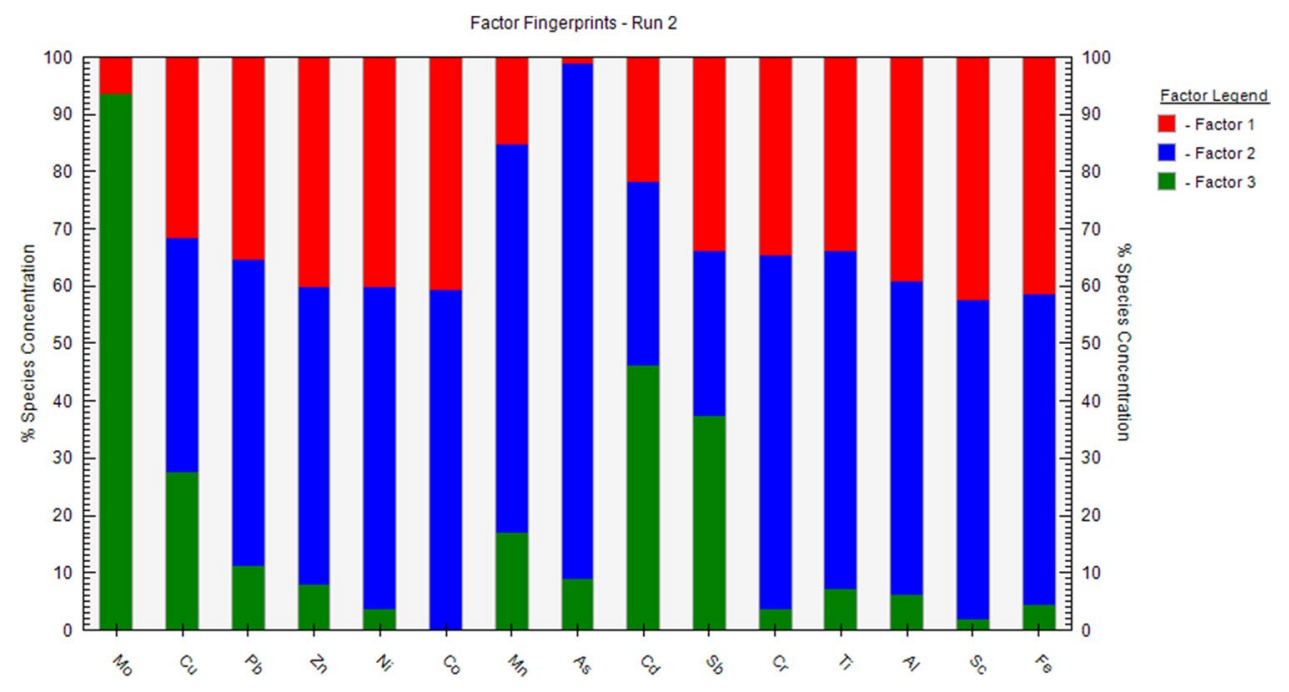

factor would describe the same pollution source (mixed natural and agricultural origins) as PC2 of PCA analysis.

Similar to PCA analysis, which indicated analogous and weak weights of $\mathrm{Cd}$ in two PCs, the cadmium contributions between F3 and (F1 and F2) of the PMF model were almost similar. However, the $E F$ and $I_{g e o}$ of $\mathrm{Cd}$ illustrated the weathering of parent rock has controlled its concentrations in soil and sediment of Hashilan wetland. Copper also showed a similar load on two principal components in the PCA analysis, while $\mathrm{Cu}$ in the PMF model accounted for $27 \%$ of factor 3 and $73 \%$ of $\mathrm{F} 1$ and $\mathrm{F} 2$, proposing the natural sources include a larger contribution of $\mathrm{Cu}$ compared to the agricultural activities.

Due to the different algorithms used by PCA and PMF models, the results of source contributions illustrate differences. Thus, the comparison of models helps to obtain more detailed information of metal(loid)s sources.

\section{Sediment-water distributions}

Some agents such as $\mathrm{pH}$, metal contents in soluble and solid phases, the values of metal complexing agents, and the physio-chemical properties of water and sediments affect the partition coefficient of elements in the water-sediment system (Allison et al. 2005). High contents of $K_{p}\left(\log K_{p}>2.9\right)$ indicate that PTEs prefer to be available in the sediment phase; whereas, low contents $\left(\log K_{p}<2.9\right)$ show that the solution has preferentially preserved the dominant portion of metal(loid)s (Jung et al. 2005).

Among the PTEs, Ni presented the highest $\mathrm{K}_{\mathrm{p}}$ with 6.25 $\mathrm{L} / \mathrm{kg}$ ( $\mathrm{S} 1$ site); whereas, the lowest $\mathrm{K}_{\mathrm{p}}$ content belonged to the $\mathrm{Cd}$ with $2 \mathrm{~L} / \mathrm{kg}$ (S5 site). The mean values of $\mathrm{K}_{\mathrm{p}}$ decreased as (L/kg): $\mathrm{Ni}(5.92)>\mathrm{Cr}(4.92)>\mathrm{Mn}(4.67)>\mathrm{Cu}$ (4.43) $>\mathrm{Co}(4.05)>\mathrm{Pb}(3.54)>\mathrm{As}$ (3.53) $>\mathrm{Zn}$ (2.96) $>\mathrm{Mo}$ (2.76) $>$ Cd (2.20) (Table S6).
Nickel, $\mathrm{Cr}, \mathrm{Mn}, \mathrm{Cu}, \mathrm{Co}$, and $\mathrm{Pb}$ indicated higher contents of $K_{p}\left(\log K_{p}>2.9\right)$ relative to other elements, proposing their lower solubility in water and higher affinity to be adsorbed to sediment samples. The relatively higher $K_{p}(\log$ $K_{p}>2.9$ ) of As and $\mathrm{Zn}$ were recognized at most stations, suggesting these elements prefer to be adsorbed in solidphase compared to soluble phase. However, As and Zn were present in the water phase at (S8, S12) and (S5, S8) stations, respectively.

In contrast, relatively lower $\mathrm{K}_{\mathrm{p}}$ of $\mathrm{Cd}\left(\log \mathrm{K}_{\mathrm{p}}<2.9\right)$ proposed the lower affinity of solid phase to adsorb this element. The distribution coefficient of Mo indicated that this element is more present in soluble phase relative to solidphase except for S3, and S8 sites due to high mobility of Mo at natural to alkaline conditions (Smedley and Kinniburgh 2017).

In the Hashilan wetland, the median $\log \mathrm{K}_{\mathrm{p}}$ contents for As, Co, Cr, Cu, Mo, and Ni were, $3.7 \mathrm{~L} / \mathrm{kg}, 4.2 \mathrm{~L} / \mathrm{kg}, 5.13$ $\mathrm{L} / \mathrm{kg}, 4.6 \mathrm{~L} / \mathrm{kg}, 2.7 \mathrm{~L} / \mathrm{kg}$, and $6.02 \mathrm{~L} / \mathrm{kg}$ respectively, which presented the higher values relative to the respective median contents for the EPA (Allison et al. 2005).

\section{Correlation of phase partition with influential factors}

Clay particles tend to adsorb heavy metals due to the negative charge and high surface area (Zhao et al. 2013). In this study, clay particles indicated the weakly positive trend with partition coefficients of $\mathrm{Cu}, \mathrm{Zn}, \mathrm{Ni}, \mathrm{Co}, \mathrm{Cd}, \mathrm{Fe}, \mathrm{Al}(r<0.5)$ and a significant opposite trend with Mo $(r=-0.8)$. Also, silt particles showed a negative correlation with partition coefficients of $\mathrm{Fe}, \mathrm{Sc}(r=-0.9)$, and $\mathrm{Cu}, \mathrm{Zn}, \mathrm{Ni}, \mathrm{Co}, \mathrm{Cr}$, As, Al $(r=-0.7)$ (Table S7). However, smaller grains are favorable to desorb or adsorb the metals (Feng et al. 2017). The positive correlation of $\mathrm{OM}$ with partition coefficients of $\mathrm{Pb}$ and $\mathrm{Mo}(\mathrm{r}=0.4)$ showed that these particles create bonds to prevent $\mathrm{Pb}$ and Mo liberation. However, a negative 
correlation of $\mathrm{OM}$ with partition coefficients of $\mathrm{Cu}, \mathrm{Ni}, \mathrm{Co}$, As, Cd, Fe, Sc, Al, and $\mathrm{Mn}(r=(-0.3)-(-0.7))$ was observed. In the investigated stations, $\mathrm{pH}$ values showed opposite trend with Mo and As ( $r=-0.9$ and -0.5 , respectively), while this parameter did not affect the distribution coefficients of the other mentioned elements (Table S7). However, although the range of $\mathrm{pH}$ fluctuations is small, varying from 6.50 to 6.88 , this factor could influence the Mo and As desorption from sediments. In this study, the effect of other influential factors like $\mathrm{Fe}-\mathrm{Mn}$ oxides concentrations in sediments, and the sorbents nature and their values in water on the metal partitioning must be examined.

\section{Agricultural nutrient pollutants and eutrophication}

In wetland ecosystems, the fate of nutrients ( $\mathrm{N}$ and $\mathrm{P})$ is determined by a combination of natural processes and human activities such as agriculture (Uwimana et al. 2018). Due to the unreasonable and excessive application of pesticides and fertilizers, and agricultural non-point source contamination has led to severe eutrophication in downstream wetlands (Yu et al. 2018). The increase in nitrate and phosphate contamination in surface water and groundwater of the study area is associated with intensive agriculture activities that are lead to an increased load of nutrient pollutants through the use of nitrogen and phosphate fertilizers. On the other hand, high $\mathrm{N}$ and $\mathrm{P}$ concentrations are the main cause of the eutrophication of wetland water. Not only do these impact the ecological character of wetlands, but they also have effects on human health and the quality of drinking water supplied from wetlands (Ramsar 2014). Therefore, in this study, the contamination of $\mathrm{N}$ and $\mathrm{P}$ compounds as nutrient pollutants in the water is compared with drinking and agricultural water standards. As shown in the Table S8, the total nitrogen (TN) concentration in water samples was varied between $8.63 \mathrm{mg} / \mathrm{l}$ and $48.16 \mathrm{mg} / \mathrm{l}$. Exceptionally high TN concentration were observed at S8 site which could be related to agricultural activities which has likely mostly increased the concentration of $\mathrm{TN}$ in the station due to the use of chemical fertilizers.

Nitrate $\left(\mathrm{NO}_{3}{ }^{-}\right)$is typically the dominant form of $\mathrm{N}$ in natural waters and polluted water. Nitrate and other forms of nitrogen in an aquatic ecosystem can originate from natural sources, but when $\mathrm{N}$ values are elevated, the sources are commonly related to anthropogenic sources (MPCA 2013). In Fig. S10 and Table S8, the values of nitrate $\left(\mathrm{NO}_{3}{ }^{-}\right)$in water sampling stations are observed. $\mathrm{NO}_{3}{ }^{-}$values in all stations (except S8) were lower than the value reported by FAO (1973). In the $\mathrm{S} 8$ station, the $\mathrm{NO}_{3}{ }^{-}$concentration was $37.08 \mathrm{mg} / \mathrm{l}$, due to water samples being taken near the farms. However, the mean $\mathrm{NO}_{3}{ }^{-}$concentration was relatively higher in wetland water $(10.39 \mathrm{mg} / \mathrm{l})$, which showed the use of massive anthropogenic fertilizers has caused an additional
$\mathrm{NO}_{3}{ }^{-}$input enters wetland water, which can pose a threat to increase the risk of water eutrophication. This is of particular importance in wetland ecosystems with a high proportion of agricultural use because their effluents are mostly enriched by $\mathrm{N}$, mainly in form of $\mathrm{NO}_{3}{ }^{-}$derived from fertilizers that are not fixed to the exchangeable soil complex. In fact, wetlands have been highlighted as valuable ecosystems to mitigate the negative impacts of $\mathrm{NO}_{3}{ }^{-}$excess because of their capacity to act as green filters (Ấlvarez-Rogel et al. 2016). On the other hand, low depth and standing water at S8 and S12 stations can also promote evaporate process, causing an increase in the concentration of pollutants. Also, all samples had nitrite $\left(\mathrm{NO}_{2}^{-}\right)$and ammonia $\left(\mathrm{NH}_{3}\right)$ values well below the FAO (1973), as shown in Table S8. The maximum $\mathrm{NO}_{2}^{-}(0.038 \mathrm{mg} / \mathrm{l})$ and $\mathrm{NH}_{3}(1.58 \mathrm{mg} / \mathrm{l})$ value was also measured at the $\mathrm{S} 8$ station. Environmental and health concerns associated with different forms of nitrogen in water can be classified as human health, aquatic life toxicity, and eutrophication. Exposure to nitrate and in some cases nitrite polluted water has notably contributed to methemoglobinemia in infants. According to the Safe Drinking Water Act standard, known as a maximum contaminant level (MCL), established by the US Environmental Protection Agency (EPA), the nitrate and nitrite concentrations in the wetland water (except at S8 station for nitrate) were below $10 \mathrm{mg} / \mathrm{l}$ and $1 \mathrm{mg} / \mathrm{l}$, respectively.

The highest concentration TP $(0.2 \mathrm{mg} / 1)$ was found in the water of the $\mathrm{S} 12$ station due to receiving effluents from agricultural lands, and the lowest value was measured $0.02 \mathrm{mg} / \mathrm{l}$ in the water of $\mathrm{S} 1$ station, which is located close to Sabz Ali spring. Both total phosphorus (TP) and phosphate $\left(\mathrm{PO}_{4}{ }^{3-}\right)$ values did not differ significantly between the different stations although TP concentration at all stations was twice high as that in the $\mathrm{PO}_{4}{ }^{3-}$ concentration, as shown in Fig. $\mathrm{S} 11$. The $\mathrm{PO}_{4}{ }^{3-}$ concentration ranged between $0.01 \mathrm{mg} / \mathrm{l}$ and $0.14 \mathrm{mg} / \mathrm{l}$ with a mean value of $0.05 \mathrm{mg} / 1$ (Table S8). Moreover, the $\mathrm{PO}_{4}{ }^{3-}$ concentration at all sampling points was below the recommended limit of $2 \mathrm{mg} / \mathrm{l}$ (FAO 1973). Increasing the $\mathrm{PO}_{4}{ }^{3-}$ concentration in water can cause accelerated growth of phytoplankton (algal blooms) and pose a threat to water eutrophication in the wetland. Nuisance algal growths are not uncommon in surface waters below the low reference level $(0.1 \mathrm{mg} / \mathrm{l})$ for $\mathrm{P}$ by recommended water quality criteria (US EPA 2002), however, the results of this study suggested that the P concentration at the S12 station is more than the reference level and can cause negative impacts in a long time on the wetland health. Zhang et al. (2003) found that in TP value between 0.16 and $0.25 \mathrm{mg} / \mathrm{l}$, the water state changes from fresh to turbid resulting in a significant decrease in the submerged vegetation. There are various sources of $\mathrm{P}$, both natural (such as soils, rocks and atmospheric precipitation) and human (including agricultural fertilizers, municipal and industrial wastewater) 
origins. Apatite $\left[\mathrm{Ca}_{5}\left(\mathrm{PO}_{4}\right)_{3}(\mathrm{~F}, \mathrm{Cl}, \mathrm{OH})\right]$ is the most abundant naturally occurring $\mathrm{P}$ containing mineral in the Earth's crust. The world's main source of phosphatic fertilizer is rock phosphate, a naturally occurring P-rich sedimentary or igneous rock containing about 5-13\% P (Nieder et al. 2018). The major external source of $\mathrm{P}$ in the water of Hashilan wetland is agricultural runoff.

To evaluate the trophic status of a water column there are no fixed or perfect assessment criteria. However, the general parameters to evaluate the trophic stage or eutrophication include dissolved oxygen concentration, water transparency, algal chlorophyll, and total nutrient concentration ( $\mathrm{P}$ and $\mathrm{N}$ ). In general, it is convenient to associate the trophic status in terms of nutrient concentration as this is the key factor controlling the eutrophication process (Bhagowati and Ahamad 2019). The general guideline for $\mathrm{N}$ and $\mathrm{P}$ concentrations indicating the different trophic states of the water column are given in Table S9. The eutrophication or red tide occurs when total nitrogen and phosphorus concentrations exceed $300 \mu \mathrm{g} / \mathrm{l}$ and $20 \mu \mathrm{g} / \mathrm{l}$, respectively (Yang et al. 2008). According to the finding of Richardson et al. (2007), threshold protective of total phosphorus for all trophic levels would best be defined as a threshold zone at $12-15 \mu \mathrm{g} / \mathrm{l}$, and exceeding surface water TP threshold value of $15 \mu \mathrm{g} / \mathrm{l}$ can cause an ecological imbalance of algal, macrophytes and other aquatic organisms. For data evaluation purposes nutrient levels in the Hashilan wetland are compared to the trophic status guidelines (Table S9). According to the trophic status classification scheme, based on the TP levels, the S2, S3, and S8 stations were at a eutrophic state. In the $\mathrm{S} 1$ station, the TP content was $0.02 \mathrm{mg} / \mathrm{l}$ and was at a mesotrophic state and the water quality of the S5 and S12 stations was hypertrophic level. Based on the mean TP concentration $(0.08 \mathrm{mg} / \mathrm{l})$, the water quality of the Hashilan wetland was at a eutrophic state. Concentrations of TP higher than $30 \mu \mathrm{g}$ $/ 1$ are generally considered favorable for eutrophication in freshwater ecosystems, provided that inorganic nitrogen or other nutrients are not limiting (De Villiers 2007). In addition, minimum and maximum $\mathrm{TN}$ concentrations indicate that all of the Hashilan wetland monitoring stations have come into hypertrophic conditions, i.e., TN values exceeding $2000 \mu \mathrm{g} / \mathrm{l}$ according to the trophic status classification scheme (Table S8 and S9). Our results indicated that TP and TN concentrations in Hashilan wetland exceeded the thresholds for algae blooms. On the other hand, increased levels of the nutrient towards the downstream of the wetland possibly reflect the intensity of human activities within the reaches of the catchment.

The ratio of $\mathrm{N}: \mathrm{P}$ in the water body (referred to as the "Redfield ratio") is an important indicator of which nutrient is limiting eutrophication. The high ratio of N:P which is greater than 16 indicates that $\mathrm{P}$ is most likely a limiting nutrient to plant growth (Zheng et al. 2019). The N:P ratio in all the water samples was higher than the Redfield ratio of 16, and was thus $\mathrm{P}$ limited. This coincided with the high inputs of $\mathrm{N}$ at this wetland (Fig. S12). Also, the N:P ratio shows that in Hashilan wetland, like most other freshwater ecosystems, is commonly P limited. In fact, phosphorus is the main limiting nutrient for the primary production of phytoplankton in many freshwater systems, while nitrogen is generally limiting in marine environments (Howarth and Marino 2006). Although excessive TP and TN in water are considered as the only factors inducing water eutrophication, nutrient enrichment is only necessary but not an adequate condition for the algal bloom. Water eutrophication can occur quickly when all of the influencing factors involving slow current velocity, excessive TP and TN, biodiversity and microbial activity, and temperature and other environmental factors are favorable (Yang et al. 2008).

\section{Conclusion}

This study focused on the distribution, fate, ecological risk assessment, and source apportionments of heavy metal(loid) $\mathrm{s}$ in sediments of Hashilan wetland. In this research, several methods for pollution and risk assessment were used, in order to best interpret the pollution state of water and sediments of the wetland. The results showed that the highest values of the investigated elements belonged to farmlands that are located near the road. However, only the mean concentrations of $\mathrm{Ni}$, $\mathrm{Cr}$, and $\mathrm{Cu}$ in sediment samples were higher than those in the world-soil average. However, $\mathrm{Ni}$ and $\mathrm{Cr}$ were moderately enriched at most stations. The moderate and significant enrichments of $\mathrm{Mo}$ and $\mathrm{Cu}$ in sediments were measured at some sampling sites where agricultural runoff enters the wetland. Due to the moderate and significant enrichments of the mentioned elements, all stations were moderately and severely polluted. Among the several methods of risk assessment, the TRI equation better presented the toxicity risk of heavy metals regarding the results of the MPI index which shows more than half of the stations pose considerable to moderate environmental risk. The highest risk contribution belonged to the Ni element.

According to the $\mathrm{EF}$ and two multivariate receptor models, $\mathrm{Pb}, \mathrm{Zn}, \mathrm{Ni}, \mathrm{Co}, \mathrm{As}, \mathrm{Mn}, \mathrm{Cr}, \mathrm{Al} \mathrm{Sc}$, and Cd were mainly originated from natural sources while $\mathrm{Mo}$ and $\mathrm{Cu}$ were derived from mixed natural and agricultural activities. High concentrations of $\mathrm{Ni}$ and $\mathrm{Cr}$ are related to the Ophiolite sequences of the Zagros fold-and-thrust belt which along with $\mathrm{Cu}$ and Mo have contaminated the sediments of most stations. Also, low pollution of TPH was observed in Hashilan sediment samples, proposing the impact of anthropogenic sources on the TPH values is low. The results indicated that the surface water of a few stations are contaminated with $\mathrm{Zn}, \mathrm{Cu}$, and $\mathrm{Cd}$. However, the ecological risks of these elements to the aquatic biota were negligible. Also, downstream stations indicated higher phosphate 
and nitrate concentrations compared to the other sites due to the entrance of agricultural effluents in this part of the wetland. According to the mean TP and TN concentrations, the water quality of the wetland was at eutrophic and hypertrophic status, respectively. Totally, monitoring and urgent actions must be done to reduce the input of nutrients into the water body.

Supplementary Information The online version contains supplementary material available at https://doi.org/10.1007/s11356-021-17937-x.

Acknowledgements This study was funded by the Cultural Heritage, Handicrafts and Tourism Organization of Iran (Natural Heritage) and the authors wish to express their gratitude to Shiraz University for logistic and technical assistance.

Author contribution Sajjad Abbasi: Initial idea, Sampling, Project manager, Project leader, Laboratory activity, Conceptualization, Methodology, Investigation, Interpretation, Writing, Review and Editing.

Sara Sheikh Fakhradini: Conceptualization, Investigation, Interpretation, Writing, Review and Editing.

Nematollah Jafarzadeh: Review and Editing.

Pooria Ebrahimi: Review and Editing.

Shirin Yavar Ashayeri: Interpretation, Writing, Review and Editing.

Funding This study was funded by the Cultural Heritage, Handicrafts and Tourism Organization of Iran (Natural Heritage).

Data availability All data generated or analyzed during this study are included in this published article [and its supplementary information files].

\section{Declarations}

Ethics approval and consent to participate Not applicable.

Consent for publication Not applicable.

Competing interests The authors declare no competing interests.

Open Access This article is licensed under a Creative Commons Attribution 4.0 International License, which permits use, sharing, adaptation, distribution and reproduction in any medium or format, as long as you give appropriate credit to the original author(s) and the source, provide a link to the Creative Commons licence, and indicate if changes were made. The images or other third party material in this article are included in the article's Creative Commons licence, unless indicated otherwise in a credit line to the material. If material is not included in the article's Creative Commons licence and your intended use is not permitted by statutory regulation or exceeds the permitted use, you will need to obtain permission directly from the copyright holder. To view a copy of this licence, visit http://creativecommons.org/licenses/by/4.0/.

\section{References}

Abbasi S, Ashayeri SY, Jafarzadeh N et al (2021) Hydrological and hydrogeological characteristics and environmental assessment of Hashilan Wetland, a national heritage in NW Iran. Ecohydrol Hydrobiol
Abbasi S, Keshavarzi B (2019) Source identification of total petroleum hydrocarbons and polycyclic aromatic hydrocarbons in PM10 and street dust of a hot spot for petrochemical production: Asaluyeh County, Iran. Sustain Cities Soc 45:214-230

Abbasi S, Keshavarzi B, Moore F, Mahmoudi MR (2018) Fractionation, source identification and risk assessment of potentially toxic elements in street dust of the most important center for petrochemical products, Asaluyeh County, Iran. Environ Earth Sci 77:673

Abbasi S, Keshavarzi B, Moore F, Shojaei N, Sorooshian A, Soltani N, Delshab H (2019) Geochemistry and environmental effects of potentially toxic elements, polycyclic aromatic hydrocarbons and microplastics in coastal sediments of the Persian Gulf. Environ Earth Sci 78:492

Abbasi S, Ashayeri SY, Jafarzadeh N, Fakhradini SS, Alirezazadeh M, Ebrahimi P, Peely AB, Rezaei N, Mokhtarzadeh Z, Naraki H (2021) Hydrological and hydrogeological characteristics and environmental assessment of Hashilan Wetland, a national heritage in NW Iran. Ecohydrology Hydrobiology. https://doi.org/10.1016/j. ecohyd.2021.08.014

Akhbarizadeh R, Moore F, Keshavarzi B, Moeinpour A (2016) Aliphatic and polycyclic aromatic hydrocarbons risk assessment in coastal water and sediments of Khark Island, SW Iran. Mar Pollut Bull 108:33-45

Allahyari K, Saccani E, Pourmoafi M, Beccaluva L, Masoudi F (2010) Petrology of mantle peridotites and intrusive mafic rocks from the Kermanshah ophiolitic complex (Zagros belt, Iran): implications for the geodynamic evolution of the NeoTethyan oceanic branch between Arabia and Iran. Ofioliti 35:71-90

Allison JD, Allison TL 2005. Partition coefficients for metals in surface water, soil, and waste. Rep. EPA/600/R-05, 74.

Álvarez-Rogel J, del Carmen Tercero M, Arce MI, Delgado MJ, Conesa HM, González-Alcaraz MN (2016) Nitrate removal and potential soil $\mathrm{N}_{2} \mathrm{O}$ emissions in eutrophic salt marshes with and without Phragmites australis. Geoderma 282:49-58. https://doi. org/10.1016/J.GEODERMA.2016.07.011

Andreu V, Gimeno-García E, Pascual JA, Vázquez-Roig P, Picó Y (2016) Presence of pharmaceuticals and heavy metals in the waters of a Mediterranean coastal wetland: potential interactions and the influence of the environment. Sci Total Environ 540:278-286

ATSDR (Agency for Toxic Substances and Disease Registry) (2017) Agency for toxic substances and disease registry, substance priority list. Available at https://www.atsdr.cdc.gov/spl.index. html\#2019spl

Azzi V, Kazpard V, Lartiges B, Kobeissi A, Kanso A, El Samrani AG (2007 Trace metals in phosphate fertilizers used in Eastern Mediterranean countries. CLEAN-Soil, Air, Water, 45(1)

Bhagowati B, Ahamad KU (2019) A review on lake eutrophication dynamics and recent developments in lake modeling. Ecohydrol Hydrobiol. https://doi.org/10.1016/j.ecohyd.2018.03.002

CCME (Canadian Council of Ministers of the Environment) (2007) Canadian Water Quality Guidelines for the Protection of Aquatic Life And Agricultural Water Uses. available at http:// ceqgrcqe.ccme.ca/en/index.html

Chen YA, Liu PWG, Whang LM, Wu YJ, Cheng SS (2020) Effect of soil organic matter on petroleum hydrocarbon degradation in diesel/fuel oil-contaminated soil. J Biosci Bioeng 129:603-612

Cui S, Zhang F, Hu P, Hough R, Fu Q, Zhang Z, An L, Li YF, Li K, Liu D (2019) Heavy metals in sediment from the urban and rural rivers in Harbin City, Northeast China. Int J Environ Res Public Health 16:4313

De Villiers S (2007) The deteriorating nutrient status of the Berg River, South Africa. Water SA 33:659-664. https://doi.org/10. 4314/wsa.v33i5.184087 
Defarge N, De Vendômois JS, Séralini GE (2018) Toxicity of formulants and heavy metals in glyphosate-based herbicides and other pesticides. Toxicol Rep 5:156-163

Dong B, Zhang R, Gan Y, Cai L, Freidenreich A, Wang K, Guo T, Wang H (2019) Multiple methods for the identification of heavy metal sources in cropland soils from a resource-based region. Sci Total Environ 651:3127-3138

Duarte B, Silva G, Costa JL, Medeiros JP, Azeda C, Sá E, Metelo I, Costa MJ, Caçador I (2014) Heavy metal distribution and partitioning in the vicinity of the discharge areas of Lisbon drainage basins (Tagus Estuary, Portugal). J Sea Res 93:101-111

FAO/Unesco (1973) Irrigation, Drainage and Salinity. An International Sourcebook. Paris, Unesco/Hutchinson (Publishers), London. p. 510

Fei X, Christakos G, Xiao R, Ren Z, Liu Y, Lv X (2019) Improved heavy metal mapping and pollution source apportionment in Shanghai City soils using auxiliary information. Sci Total Environ 661:168-177

Feng C, Guo X, Yin S, Tian C, Li Y, Shen Z (2017) Heavy metal partitioning of suspended particulate matter-water and sediment-water in the Yangtze Estuary. Chemosphere 185:717-725

Gao L, Wang Z, Shan J, Chen J, Tang C, Yi M, Zhao X (2016) Distribution characteristics and sources of trace metals in sediment cores from a trans-boundary watercourse: An example from the Shima River, Pearl River Delta. Ecotoxicol Environ Saf 134:186-195

Gimeno-García E, Andreu V, Boluda R (1996) Heavy metals incidence in the application of inorganic fertilizers and pesticides to rice farming soils. Environ Pollut 92:19-25

Guan Q, Zhao R, Pan N, Wang F, Yang Y, Luo H (2019) Source apportionment of heavy metals in farmland soil of Wuwei, China: comparison of three receptor models. J Clean Prod 237:117792

Gupta DK, Chatterjee S, Datta S, Veer V, Walther C (2014) Role of phosphate fertilizers in heavy metal uptake and detoxification of toxic metals. Chemosphere 108:134-144

Harikrishnan N, Ravisankar R, Chandrasekaran A, Gandhi MS, Kanagasabapathy KV, Prasad MVR, Satapathy KK (2017) Assessment of heavy metal contamination in marine sediments of east coast of Tamil Nadu affected by different pollution sources. Mar Pollut Bull 121:418-424

Hou D, He J, Lü C, Ren L, Fan Q, Wang J, Xie Z (2013) Distribution characteristics and potential ecological risk assessment of heavy metals $(\mathrm{Cu}, \mathrm{Pb}, \mathrm{Zn}, \mathrm{Cd})$ in water and sediments from Lake Dalinouer, China. Ecotoxicol Environ Saf 93:135-144

Howarth RW, Marino R (2006) Nitrogen as the limiting nutrient for eutrophication in coastal marine ecosystems: Evolving views over three decades. In: Limnol Oceanogr:364-376. https://doi.org/10. 4319/lo.2006.51.1_part_2.0364

Hu C, Yang X, Dong J, Zhang X (2018) Heavy metal concentrations and chemical fractions in sediment from Swan Lagoon, China: Their relation to the physiochemical properties of sediment. Chemosphere 209:848-856

Huang B, Yuan Z, Li D, Zheng M, Nie X, Liao Y (2020) Effects of soil particle size on the adsorption, distribution, and migration behaviors of heavy metal (loid) s in soil: a review. Environ Sci Process Impacts 22:1596-1615

Islam, MS, Hossain, MB, Matin, A, Sarker, MSI (2018) Assessment of heavy metal pollution, distribution and source apportionment in the sediment from Feni River estuary, Bangladesh. Chemosphere 202: 25-32.

Ji Z, Zhang H, Zhang Y, Chen T, Long Z, Li M, Pei Y (2019) Distribution, ecological risk and source identification of heavy metals in sediments from the Baiyangdian Lake, Northern China. Chemosphere 237:124425

Ji Z, Zhang Y, Zhang H, Huang C, Pei Y (2019b) Fraction spatial distributions and ecological risk assessment of heavy metals in the sediments of Baiyangdian Lake. Ecotoxicol Environ Saf 174:417-428

Jin G, Fang W, Shafi M, Wu D, Li Y, Zhong B, Ma J, Liu D (2019) Source apportionment of heavy metals in farmland soil with application of APCS-MLR model: a pilot study for restoration of farmland in Shaoxing City Zhejiang, China. Ecotoxicol Environ Saf 184:109495

Jung HB, Yun ST, Mayer B, Kim SO, Park SS, Lee PK (2005) Transport and sediment-water partitioning of trace metals in acid mine drainage: an example from the abandoned Kwangyang $\mathrm{Au}-\mathrm{Ag}$ mine area, South Korea. Environ Geol 48:437-449

Khalil M, El-Gharabawy S (2016) Evaluation of mobile metals in sediments of Burullus Lagoon, Egypt. Mar Pollut Bull 109:655-660

Kucuksezgin F, Kontas A, Altay O, Uluturhan E, Darılmaz E (2006) Assessment of marine pollution in Izmir Bay: Nutrient, heavy metal and total hydrocarbon concentrations. Environ Int 32:41-51

Kucuksezgin F, Pazi I, Gonul LT (2012) Marine organic pollutants of the Eastern Aegean: Aliphatic and polycyclic aromatic hydrocarbons in Candarli Gulf surficial sediments. Mar Pollut Bull 64:2569-2575

Li L, Shen X, Jiang M (2019) Characteristics of total petroleum hydrocarbon contamination in sediments in the Yangtze Estuary and adjacent sea areas. Cont Shelf Res 175:110-115

Li M, Zhang Q, Sun X, Karki K, Zeng C, Pandey A, Rawat B, Zhang F (2020) Heavy metals in surface sediments in the trans-Himalayan Koshi River catchment: Distribution, source identification and pollution assessment. Chemosphere 244:125410

Liang J, Feng C, Zeng G, Gao X, Zhong M, Li X, Li X, He X, Fang Y (2017) Spatial distribution and source identification of heavy metals in surface soils in a typical coal mine city, Lianyuan, China. Environ Pollut 225:681-690

Lin YC, Tsai CJ, Wu YC, Zhang R, Chi KH, Huang YT, Lin SH, Hsu SC (2015) Characteristics of trace metals in traffic-derived particles in Hsuehshan Tunnel, Taiwan: size distribution, potential source, and fingerprinting metal ratio. Atmos Chem Phys 15:4117-4130

Lin S-S, Shen S-L, Zhou A, Xu Y-S (2020) Approach based on TOPSIS and Monte Carlo simulation methods to evaluate lake eutrophication levels. Water Res 187:116437

Lin S-S, Shen S-L, Zhou A, Lyu H-M (2021) Assessment and management of lake eutrophication: A case study in Lake Erhai, China. Sci Total Environ 751:141618

Liu Q, Jia Z, Li S, Hu J (2019) Assessment of heavy metal pollution, distribution and quantitative source apportionment in surface sediments along a partially mixed estuary (Modaomen, China). Chemosphere 225:829-838

Lu Q, Bai J, Zhang G, Wu J (2020) Effects of coastal reclamation history on heavy metals in different types of wetland soils in the Pearl River Delta: Levels, sources and ecological risks. J Clean Prod 272:122668

Lv J (2019) Multivariate receptor models and robust geostatistics to estimate source apportionment of heavy metals in soils. Environ Pollut 244:72-83

Lyu H-M, Shen S-L, Zhou A (2021) The development of IFN-SPA: A new risk assessment method of urban water quality and its application in Shanghai. J Clean Prod 282:124542

Maanan M, Saddik M, Maanan M, Chaibi M, Assobhei O, Zourarah B (2015) Environmental and ecological risk assessment of heavy metals in sediments of Nador lagoon, Morocco. Ecol Ind 48:616-626

Malcolm RL, Kennedy VC (1970) Variation of cation exchange capacity and rate with particle size in stream sediment. Journal (Water Pollution Control Federation), pp.R153-R160

Mao L, Liu L, Yan N, Li F, Tao H, Ye H, Wen H (2020) Factors controlling the accumulation and ecological risk of trace metal (loid) s in river sediments in agricultural field. Chemosphere 243:125359 
Mohebbi-Nozar SL, Zakaria MP, Ismail WR, Mortazawi MS, Salimizadeh M, Momeni M, Akbarzadeh G (2015) Total petroleum hydrocarbons in sediments from the coastline and mangroves of the northern Persian Gulf. Mar Pollut Bull 95:407-411

MPCA (Minnesota Pollution Control Agency) (2013) Nitrogen in Minnesota surface waters: Conditions, trends, sources, and reductions. Available at https://www.pca.state.mn.us/6fwc9hw

Mzoughi N, Dachraoui M, Villeneuve J-P (2005) Evaluation of aromatic hydrocarbons by spectrofluorometry in marine sediments and biological matrix: what reference should be considered? C R Chim 8:97-102

Namaghi HH, Karami GH, Saadat S (2011) A study on chemical properties of groundwater and soil in ophiolitic rocks in Firuzabad, east of Shahrood, Iran: with emphasis to heavy metal contamination. Environ Monit Assess 174:573-583

Nieder R, Benbi DK, Reichl FX (2018) Soil components and human health, Soil Components and Human Health. Springer Netherlands, Dordrecht. https://doi.org/10.1007/978-94-024-1222-2

Qiutong X, Mingkui Z (2017) Source identification and exchangeability of heavy metals accumulated in vegetable soils in the coastal plain of eastern Zhejiang province, China. Ecotoxicol Environ Saf 142:410-416

Quiñonez-Plaza A, Wakida FT, Temores-Peña J, Rodriguez-Mendivil DD, Garcia-Flores E, Pastrana-Corral MA, Melendez-Lopez SG (2017) Total petroleum hydrocarbons and heavy metals in road-deposited sediments in Tijuana, Mexico. J Soils Sediments 17:2873-2886

Ramsar (2014) Wetlands \& Agriculture : Partners for Growth. 2nd World Wetlands Day 1-16

Richardson CJ, King RS, Qian SS, Vaithiyanathan P, Qualls RG, Stow CA (2007) Estimating ecological thresholds for phosphorus in the Everglades. Environ Sci Technol 41:8084-8091. https://doi.org/10. 1021/es062624w

Sheikh Fakhradini S, Moore F, Keshavarzi B, Lahijanzadeh A (2019) Polycyclic aromatic hydrocarbons (PAHs) in water and sediment of Hoor Al-Azim wetland, Iran: a focus on source apportionment, environmental risk assessment, and sediment-water partitioning. Environ Monit Assess 191:233

Smedley PL, Kinniburgh DG (2017) Molybdenum in natural waters: A review of occurrence, distributions and controls. Appl Geochem 84:387-432

Strady E, Dinh QT, Némery J, Nguyen TN, Guédron S, Nguyen NS, Denis H, Nguyen PD (2017) Spatial variation and risk assessment of trace metals in water and sediment of the Mekong Delta. Chemosphere 179:367-378

Suresh G, Sutharsan P, Ramasamy V, Venkatachalapathy R (2012) Assessment of spatial distribution and potential ecological risk of the heavy metals in relation to granulometric contents of Veeranam lake sediments, India. Ecotoxicol Environ Saf 84:117-124

Taylor SR, McLennan SM (1985) The continental crust: its composition and evolution. Blackwell, Oxford, p 312

Tuboi C, Irengbam M, Hussain SA (2018) Seasonal variations in the water quality of a tropical wetland dominated by floating meadows and its implication for conservation of Ramsar wetlands. Phys Chem Earth A/B/C 103:107-114

USEPA (United States Environmental Protection Agency) (2012) 2012 Edition of the drinking water standards and health advisories. EPA 822-S-12-001

Ustaoğlu F, Islam MS (2020) Potential toxic elements in sediment of some rivers at Giresun, Northeast Turkey: A preliminary assessment for ecotoxicological status and health risk. Ecol Indic 113:106237
Uwimana A, van Dam AA, Gettel GM, Irvine K (2018) Effects of agricultural land use on sediment and nutrient retention in valley-bottom wetlands of Migina catchment, southern Rwanda. J Environ Manage 219:103-114. https://doi.org/10.1016/j.jenvman.2018.04.094

Vane CH, Harrison I, Kim AW, Moss-Hayes V, Vickers BP, Horton BP (2008) Status of organic pollutants in surface sediments of Barnegat bay-little Egg Harbor Estuary, New Jersey, USA. Mar Pollut Bull 56:1802-1808

Venkatachalapathy R, Veerasingam S, Basavaiah N, Ramkumar T (2010) Comparison between petroleum hydrocarbon concentrations and magnetic properties in Chennai coastal sediments, Bay of Bengal, India. Mar Pet Geol 27:1927-1935

WHO (World Health Organization) (2017) Guidelines for drinking-water quality, 4th edition, incorporating the 1 st addendum. Available at https://www.who.int/publications/i/item/9789241549950

WSRC (Westinghouse Savannah River Site) (1999) Ecological Constituents of Potential Concern Selection Process. Protocol aquatic toxicity reference values (TRVs). Westinghouse Savannah River Company, Savannah River Site, Aiken, SC. Available at www.srs. gov/general/programs/soil/ffa/rdh/p76.PDF

Wu SS, Han RM, Yang H, Bi FZ, Wang QJ, Wang YH (2017) Characterization of Metals in Surface Sediments from Xiaoyang River, Jiangsu, China. Anal Lett 50:1669-1690

Wu J, Margenot AJ, Wei X, Fan M, Zhang H, Best JL, Wu P, Chen F, Gao C (2020) Source apportionment of soil heavy metals in fluvial islands, Anhui section of the lower Yangtze River: comparison of APCS-MLR and PMF. J Soils Sediments 20: 3380-3393. https:// doi.org/10.1007/s11368-020-02639-7

Xiao H, Shahab A, Li J, Xi B, Sun X, He H, Yu G (2019) Distribution, ecological risk assessment and source identification of heavy metals in surface sediments of Huixian karst wetland. China. Ecotoxicol Environ Saf 185:109700

Yang XE, Wu X, Hao HL, He ZL (2008) Mechanisms and assessment of water eutrophication. J Zhejiang Univ Sci B. https://doi.org/10. 1631/jzus.B0710626

YavarAshayeri N, Keshavarzi B (2019) Geochemical characteristics, partitioning, quantitative source apportionment, and ecological and health risk of heavy metals in sediments and water: A case study in Shadegan Wetland, Iran. Mar Pollut Bull 149:110495

Yu X, Mingju E, Sun M, Xue Z, Lu X, Jiang M, Zou Y (2018) Wetland recreational agriculture: Balancing wetland conservation and agro-development. Environ Sci Policy 87:11-17. https://doi.org/10. 1016/j.envsci.2018.05.015

Yuanan H, He K, Sun Z, Chen G, Cheng H (2020) Quantitative source apportionment of heavy metal (loid) $s$ in the agricultural soils of an industrializing region and associated model uncertainty. J Hazard Mater 391:122244

Zeng J, Han G, Wu Q, Tang Y (2019) Heavy metals in suspended particulate matter of the Zhujiang River, southwest China: contents, sources, and health risks. Int J Environ Res Public Health 16:1843

Zhang J, Jørgensen SE, Beklioglu M, Ince O (2003) Hysteresis in vegetation shift - Lake Mogan prognoses. Ecol Model 164:227-238. https://doi.org/10.1016/S0304-3800(03)00050-4

Zhang H, Cheng S, Li H, Fu K, Xu Y (2020) Groundwater pollution source identification and apportionment using PMF and PCAAPCA-MLR receptor models in a typical mixed land-use area in Southwestern China. Sci Total Environ 741:140383

Zhao S, Feng C, Wang D, Liu Y, Shen Z (2013) Salinity increases the mobility of $\mathrm{Cd}, \mathrm{Cu}, \mathrm{Mn}$, and $\mathrm{Pb}$ in the sediments of Yangtze Estuary: relative role of sediments' properties and metal speciation. Chemosphere 91:977-984 
Zheng Z, Xu Y, Wang J, Li Y, Gu B (2019) Environmental stress and eutrophication in freshwater wetlands: evidence from carbon and nitrogen stable isotopes in cattail (Typha domingensis Pers.). Ecol Process 8:31. https://doi.org/10.1186/s13717-019-0186-4

Zhou R, Qin X, Peng S, Deng S (2014) Total petroleum hydrocarbons and heavy metals in the surface sediments of Bohai Bay, China: long-term variations in pollution status and adverse biological risk. Mar Pollut Bull 83:290-297

Zhu L, Liu J, Xu S, Xie Z (2017) Deposition behavior, risk assessment and source identification of heavy metals in reservoir sediments of Northeast China. Ecotoxicol Environ Saf 142:454-463
Zhu H, Bing H, Wu Y, Zhou J, Sun H, Wang J, Wang X (2019) The spatial and vertical distribution of heavy metal contamination in sediments of the Three Gorges Reservoir determined by anti-seasonal flow regulation. Sci Total Environ 664:79-88

Publisher's note Springer Nature remains neutral with regard to jurisdictional claims in published maps and institutional affiliations. 